\title{
Shoreline evolution and modern beach sand composition along a coastal stretch of the Tyrrhenian Sea, southern Italy
}

\author{
Consuele Morrone and Fabio letto *(D)
}

\begin{abstract}
This contribution focuses on a multidisciplinary research showing the geomorphological evolution and the beach sand composition of the Tyrrhenian shoreline between Capo Suvero promontory and Gizzeria Lido village (Calabria, southern Italy). The aim of the geomorphological analysis was to reconstruct the evolutionary shoreline stages and the present-day sedimentary dynamics along approximately $6 \mathrm{~km}$ of coastline. The results show a general trend of beach nourishment during the period 1870-2019. In this period, the maximum shoreline accretion value was estimated equal to $+900 \mathrm{~m}$ with an average rate of $+6.5 \mathrm{~m} / \mathrm{yr}$. Moreover, although the general evolutionary trend is characterized by a remarkable accretion, the geomorphological analysis highlighted continuous modifications of the beaches including erosion processes. The continuous beach modifications occurred mainly between 1953 and 1983 and were caused mainly by human activity in the coastal areas and inside the hydrographic basins. The beach sand composition allowed an assessment of the mainland petrological sedimentary province and its dispersal pattern of the present coastal dynamics. Petrographic analysis of beach sands identified a lithic metamorphi-clastic petrofacies, characterized by abundant fine-grained schists and phyllites sourced from the crystalline terrains of the Coastal Range front and carried by the Savuto River. The sand is also composed of a mineral assemblage comparable to that of the Amato River provenance. In terms of framework detrital constituents of QFL (quartz: feldspars:aphanitic lithic fragments) and of essential extraclasts, such as granitoid:sedimentary:metamorphic phaneritic rock fragments (Rg:Rs:Rm), sand maturity changes moderately from backshore to shoreface, suggesting that transport processes had a little effect on sand maturity. Moreover, the modal composition suggests that the Capo Suvero promontory does not obstruct longshore sand transport from the north. Indeed, sands displaced by currents driven by storm-wave activity bypass this rocky headland.
\end{abstract}

Keywords: Sandy petrofacies, Detrital modes, Shoreline evolution, Capo Suvero, Tyrrhenian coast, Southern Italy

\section{Introduction}

The coastal zone is regarded as one of the most vulnerable areas on the planet, consisting of highly dynamic environments and geomorphological complex systems (e.g. Dawson et al. 2009; Di Paola et al. 2013). The deterioration of coastal area, the loss of estuaries and the destruction of human heritage are some of the harmful

\footnotetext{
*Correspondence: fabio.ietto@unical.it

Department of Biology, Ecology and Earth Sciences (DiBEST), University of study Calabria, Via P. Bucci, cubo 15B, 87036 Arcavacata di Rende, Cosenza, Italia
}

effects of coastal erosion processes and of inundation, producing economic instability for mankind (Nicholls and Hoozemans 1996; Parry et al. 2007; Forbes 2009; lvã et al. 2013; Ietto et al. 2014). Currently, at least Spain (e.g. Anfuso and Gracia 2005; Del Río et al. 2013), France (e.g. Gervais et al. 2012; Castelle et al. 2015), Portugal (e.g. Ferreira 2006), Italy (Lupia Palmieri and Raffi 1983; Pranzini and Rossi 2014; Cantasano et al. 
2017), United Kingdom (e.g. Phillips and Jones 2006), elsewhere in California (e.g. Moore et al. 1999; Hapke et al. 2009) and in many other countries. Accordingly, the scientific community has significantly increased studies on geomorphological coast dynamics to safeguard the littoral areas (e.g. Komar 1998; Masselink and Hughes 2003; Bakker 2013; Bagdanavičiūtè et al. 2015; Semedi et al. 2016).

This research provides new insights into the geomorphologic evolution and into the analyses of the modern sand composition along a $6 \mathrm{~km}$ stretch of the Calabria Tyrrhenian coast, southern Italy (Fig. 1a).

The Tyrrhenian borderland of Calabria is a highly uplifted mountain belt dominantly composed of carbonate rocks to the north and by metamorphic, ophiolitic and igneous rocks towards the south (e.g. AmodioMorelli et al. 1976). The tectonic history of this area is complex (Carrara and Zuffa 1976), and the modern setting includes a mountain coast with high fluvial discharge and sedimentation rates in both the shelf environment (e.g. Chiocci 1994) and the deep marine Paola Basin (Trincardi et al. 1995; Mongardi et al. 2004). Previous studies (Le Pera and Critelli 1997; Le Pera et al. 2000; Critelli and Le Pera 2003) discussed the main detrital mineralogy of river and backshore beach sands between Scalea and the Santa Eufemia Gulf along the northern Calabria Tyrrhenian coast, discriminating three petrologic provinces (Lao Littoral Province, Coastal Range Littoral Province, and Santa Eufemia Littoral Province) with distinct detrital modes. Other researches on coastal environments dealt with the evolutionary shoreline trend of the Calabria Tyrrhenian coast (e.g. D'Alessandro and Lupia Palmieri 1981; D'Alessandro et al. 1992, 2002; Ietto 2001; Ietto et al. 2012a; Punzo et al. 2016) and with the assessment of coastal vulnerability (e.g. Guiducci and Paolella 2004; Ietto et al. 2018a; Cantasano et al. 2020).

This research represents a further extension of the previous works because it is based on a historical shoreline evolution study integrated with a petrographic analysis assessed for backshore and shoreface environment sand-samples.

The studied coastline at the northern edge of the Santa Eufemia Gulf extends from the Capo Suvero promontory in the north to Gizzeria Lido in the south (Fig. 1b). This area is the only stretch of the Calabria Tyrrhenian coast where spits and coastal lakes known as La Vota and Maricello lakes are still present, forming a priority protected habitat designated as Site of Community Interest (SIC Area) since 1995 (Caprio et al. 1999). Major geomorphic features of the area are spits, dune and marsh deposits that in the last century suffered intense natural changes through erosion and accretion processes (e.g. Ietto et al. 2012a). However, only little scientific literature exists (Mongardi et al. 2004; Ietto et al. 2012a), which documents the geomorphological setting of this coastal area. This research attempts to take a step forward with respect to previous studies because it uses a multidisciplinary approach based on a detailed geomorphological analysis and on compositional parameters of the sandy detritus. In this regard, the main goals of this research can be summarized as following:

1) Reconstruction of the geomorphological evolution of the beach in the last 150 years;

2) Characterization of shoreface and backshore sand composition and provenance;

3) Analysis of the factors controlling the geomorphological beach evolution.

The obtained results intend to increase the knowledge both on the geomorphological processes and on the petrographic features of the beaches, highlighting the useful contribution of the detrital mineralogy analysis of the sandy fraction for the investigation.

\section{Study area}

\subsection{Geology}

Calabria of southern Italy is an arcuate portion of the Neogene Apennine-Maghrebide orogenic belt known as Calabria-Peloritani Arc or CPA (e.g. Amodio-Morelli et al. 1976), which represents an accretionary wedge caused by the Africa-Europe collision (Ghisetti and Vezzani 1982; Dewey et al. 1989; Vai 1992). The CPA is made of crystalline basement nappes partially affected by Alpine metamorphism (Ortolano et al. 2005; Pezzino et al. 2008), and some of these are covered by MesoCenozoic sedimentary deposits (e.g. Critelli and Le Pera 1994, 1995). Since the Pliocene, the tectonic evolution of the CPA is characterised by extensional fault systems that fragmented the orogen into structural highs and subsiding basins (Tortorici et al. 1995; Galli and Bosi 2002; Catalano and De Guidi 2003).

Starting from the Lower-Middle Pleistocene, the Calabria terrains underwent a strong regional uplift that is still active (Westaway 1993; Ietto and Ietto 2004; Antonioli et al. 2006). The uplift process has been responsible for reliefs with high erosional energy and continuous rejuvenation of the hydrographic network, causing a high erosion rate (Ietto et al. 2015, 2016, 2018b; Conforti and Ietto 2019). The Holocene uplift values range from 0.6 $\mathrm{mm} / \mathrm{yr}$ up to $1.5 \mathrm{~mm} / \mathrm{yr}$ on the Calabria Tyrrhenian side (e.g. Ferranti et al. 2010), making sea-level changes, due to ice sheet melting, negligible, because both processes seem to have the same increasing order, ending up to compensate each other (e.g. Pirazzoli et al. 1997). 


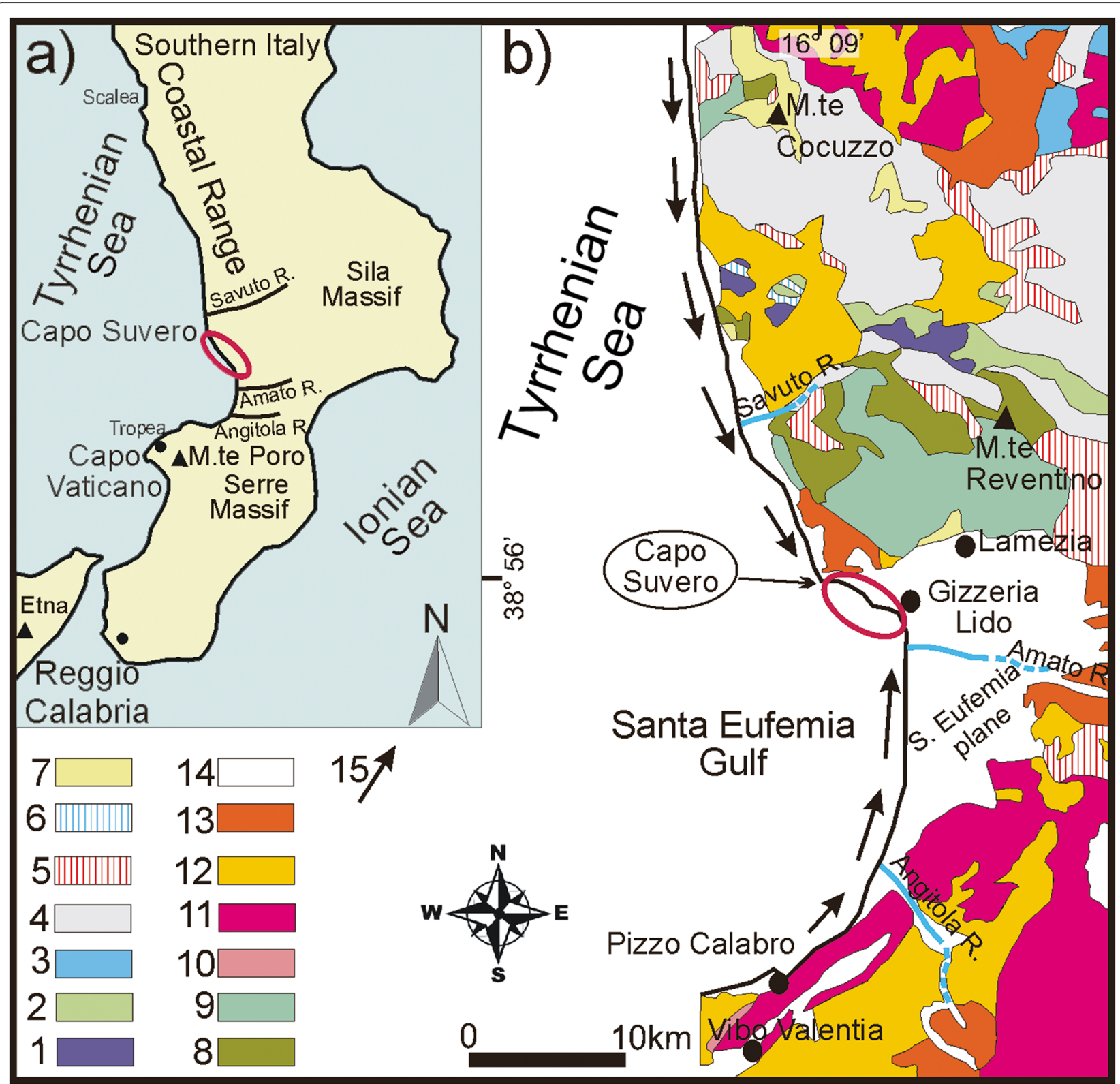

Fig. 1 a Sketch map showing the location of the studied coastline highlighted in the red circle; $\mathbf{b}$ Geologic map of the study area (modified from Amodio-Morelli et al. 1976; Critelli and Le Pera 2003): 1 - Pre-Carboniferous biotitic paragneiss; 2 - Carboniferous granodiorites; 3 Carboniferous garnet-sillimanite gneiss and pyroxene-bearing amphibolites; 4 - Carboniferous phyllites and amphibolites; 5 - Pre-Triassic biotitemuscovite gneiss, micaschists, amphibolites and metagreywackes; 6 - Triassic-Upper Cretaceous limestones and dolostones; 7 - Upper TriassicMiocene metalimestones; 8 - Jurassic-Lower Cretaceous blue schist and serpentinites; 9 - Cretaceous slates, metaquartzarenites and metalimestones; 10 - Cretaceous-Paleogene tonalitic gneiss; 11 - Cretaceous-Paleogene garnet-sillimanite gneiss; 12 - Upper Miocene-Lower Pliocene clays, sandstones and conglomerates; 13 - Middle Pliocene-Lower Pleistocene calcarenites, sand, clay and conglomerates; 14 Holocene sediments; 15 - Littoral drift. M. = Mountain; R. = River

The study area lies in the northern part of the CPA along a coastal stretch between the Savuto and the Amato river-mouths. In particular, the coastal area, located at the foot of the Coastal Range, includes the beaches of the southern side of the Capo Suvero promontory, forming the north side of the Santa Eufemia Gulf (Fig. 1).
The Coastal Range, a 75-km-long N-S trending mountain chain, is bounded by active east-dipping normal faults approximately coincident with the coastal scarp (Sorriso-Valvo and Sylvester 1993). It is made up of nearly flat-lying nappes, including a variety of Palaeozoic and Mesozoic to Paleogene terranes (Fig. 1b), ranging from high- to middle- to low-grade metamorphic, 
ophiolitic, plutonic and sedimentary rocks (e.g. AmodioMorelli et al. 1976; Carrara and Zuffa 1976). These rocks are unconformably covered by Miocene to Quaternary deposits (e.g. Ortolani et al. 1979). Palaeozoic terranes are gneiss, amphibolite with minor harzburgite and serpentinite, granite and granodiorite. Mesozoic and Paleogene rocks include limestone, dolostone, slate and ophiolite; whereas Neogene and Quaternary strata include sandstone, hybrid arenites, conglomerate, claystone, marl, minor gypsum and limestone (e.g. AmodioMorelli et al. 1976; Morten and Tortorici 1993; Iannace et al. 2005) (Fig. 1b). The Santa Eufemia coastal plain includes the wide fluvial plain of the Amato River and the northern flank of the Poro Plateau having dominantly plutonic and high-grade metamorphic rocks.

Previous studies (Le Pera and Critelli 1997; Le Pera et al. 2000; Critelli and Le Pera 2003) illustrated the main mineralogy of fluvial, beach and deep-sea sand, collected along the Tyrrhenian coast of Calabria, between Scalea and the Santa Eufemia Gulf. The same authors allocated the study area in a distinct petrologic province named Santa Eufemia Littoral Province supplied by the mouths of several torrential-type drainages and from the fluvial systems of the Amato and Angitola rivers (Fig. 1b).

The Amato River flows in the southern portion of the studied site with a basin area equal to $441 \mathrm{~km}^{2}$, which is bounded on the north side by the Sila Massif and on the south by the Serre Massif. These massifs are composed primarily by Paleozoic plutonic rocks (mainly granodiorite and tonalite) and gneiss, with minor Mesozoic to Paleogene ophiolitic rocks and Miocene to Quaternary clastic sedimentary rocks (e.g. Bonardi et al. 2001). Therefore, the drainage area is characterized by dominant metamorphic and minor sedimentary and plutonic source rocks.

The Angitola River has a basin area of $199 \mathrm{~km}^{2}$; it flows mainly across the plutonic rocks of the Serre Massif and the clastic sedimentary rocks of the Santa Eufemia Plain (Fig. 1b). The Angitola river-mouth lies in the southern side of the Santa Eufemia Gulf.

The Savuto River, located about $10 \mathrm{~km}$ to north of the Capo Suvero promontory (Fig. 1b), flows across the Coastal Range. The drainage area is nearly $412 \mathrm{~km}^{2}$ and is dominated by abundant low- to high-grade metamorphic rocks and minor ophiolitic, plutonic and sedimentary rocks. Therefore, the physiographic units of the studied coastal stretch are, from north to south, the Savuto river-mouth, the narrow Coastal Range and the Santa Eufemia coastal plain (Fig. 1b).

\subsection{Climate and geomorphology}

Calabria currently experiences a Mediterranean climate with a strong altitude-dependent zonation of temperature and rainfall. In the studied Tyrrhenian margin, the average annual value of rainfall is high, with precipitation ranging from $600-1000 \mathrm{~mm}$ to more than $1800 \mathrm{~mm}$ in lower and higher elevations of the Coastal Range, respectively (Caloiero 1975; Petrucci et al. 1996), overcoming the average trend of the whole Italian Peninsula $(970 \mathrm{~mm} / \mathrm{yr})$. This is because the Coastal Range mountains trap precipitations from frontal storms moving inland from the Tyrrhenian Sea. Thus, the climate ranges from Mediterranean semiarid and moderately seasonal thermic on the piedmont to Mediterranean humid or subhumid and moderately seasonal mesic in the mountains below 1000-1200 ma.s.l. (Le Pera and Sorriso-Valvo 2000a). Above this altitude, the Coastal Range is humid and mesic with snowfalls that alternate with heavy downpours during the winter season. The mean annual temperature ranges from $12^{\circ} \mathrm{C}$ to more than $16^{\circ} \mathrm{C}$ for the Tyrrhenian coastal zone (Versace et al. 1989).

Tectonic uplift (e.g. Westaway 1993; Ferranti et al. 2010), slope instability (e.g. Conforti and Ietto 2020), erosion and weathering processes (e.g. Sorriso-Valvo and Sylvester 1993; Ietto et al. 2012b; Perri et al. 2016) have been important in shaping the geomorphology of the Calabria mountain range, where morphodynamic processes are of high magnitude (Sorriso-Valvo et al. 1998; Calcaterra and Parise 2010; Ietto et al. 2013; Ietto and Perri 2015). The Calabria mountain range is in various stages of dissection, and the erosion and weathering degree is dependent on their relative age of exhumation (Sorriso-Valvo 1993; Thomson 1994). Moreover, weathering and erosion may vary markedly for individual $\mathrm{Ca}$ labria mountains because of the effects of topography, lithology and climate (Ibbeken and Schleyer 1991; Le Pera and Sorriso-Valvo 2000b). In general, chemical weathering is more important than mechanical disintegration for the Sila and Serre massif rocks, where thick and moderately mature soils are exposed along ridge crests and in stream cuts (Le Pera et al. 2001). Conversely, the lowest rates of chemical denudation are found on the Coastal Range, characterized by slopes steeper than the ones of the Sila and Serre massifs, where the low rates correlate with rapid mass-wasting processes (Le Pera and Sorriso-Valvo 2000a). The latter are widespread and distributed throughout the Coastal Range mainly on the Tyrrhenian side (Sorriso-Valvo and Sylvester 1993; Ietto and Perri 2015), leading to high sedimentation rates in adjacent sedimentary basins, in both continental (Le Pera and Critelli 1997) and shelf environments (Chiocci 1994; Le Pera et al. 2000), as well as in the deep marine Paola Basin (Trincardi et al. 1995). Slope instability is widespread on the Coastal Range, with an area incidence that ranges from $15 \%$ to $20 \%$ up to maximum values of $40 \%$ in drainage basins where phyllitic rocks occur (Sorriso-Valvo and Sylvester 1993). 
Sediment of exceptional thickness was deposited on the Tyrrhenian continental shelf during the Holocene (e.g. Chiocci et al. 1989), giving rise to widespread geomorphological changes in littoral areas of Calabria. The coarse-grained clastic sediment, deposited at the coast surrounding the study area, was mainly supplied by the Savuto and Amato rivers perennially and by torrential streams during times of high surface run-off (SorrisoValvo et al. 1998).

\subsection{Wave regime and coastal morphology}

Sea-waves provide the dominant controlling process for shore morphology and sediment redistribution in the littoral areas (e.g. D'Alessandro et al. 2002). In the study area, the wave-fetch window is oriented between North $230^{\circ}$ and North $320^{\circ}$ (Fig. 2a), so the transfer of energy from the wind to the sea is between the IIIrd and IVth quadrant. These winds can reach a speed of up to $26 \mathrm{~m} /$ $\mathrm{s}$. The wind data were obtained by a private weather station located on the beach of the study area, while the statistical analysis of offshore waves was provided by the Italian Sea Wave Measurement (Rete Ondametrica Nazionale 2019) from the Cetraro buoy (Fig. 2a), which is located offshore Cetraro village $\left(39^{\circ} 27^{\prime} 2^{\prime \prime} \mathrm{N} ; 15^{\circ} 55^{\prime} 1^{\prime \prime}\right.$ E) and has been working since 1999. The data collected by the Cetraro buoy are representative of the offshore wave conditions in the study area, according to the Wind and Wave Atlas of the Mediterranean Sea (Gaillard et al. 2004). The considered period for the sea climate analysis ranges from year 2004 to year 2007 and includes values of significant wave height and mean wave direction (Fig. 2b). The data show that the prevailing winds blow from NW where the average geographic fetch is equal to $600 \mathrm{~km}$. The mean wave approaching the coast from NW direction has a significant offshore height of $2-3 \mathrm{~m}$ (regnant wave) (Fig. 2b). The highest wave with a significant offshore height greater than $5 \mathrm{~m}$ (dominant wave) propagates from WSW, where the geographic fetch reaches $1300 \mathrm{~km}$. It should be noted that sea-wave values are measured offshore, and significant changes in wave height can occur nearshore as a result of shoaling effects (e.g. James 1974). The winds blow also from the IInd quadrant (east-southeast), with a speed of up to $20-24 \mathrm{~m} / \mathrm{s}$, without producing waves nearshore because winds are offshore oriented. The collected data display that the study area is located in a relatively high-energy coastal environment, where the washover phenomenon can involve all beach width during big storms.

The continental shelf on the Calabria Tyrrhenian side has an average width of $5 \mathrm{~km}$, but in the Capo Suvero surroundings the continental shelf is instead

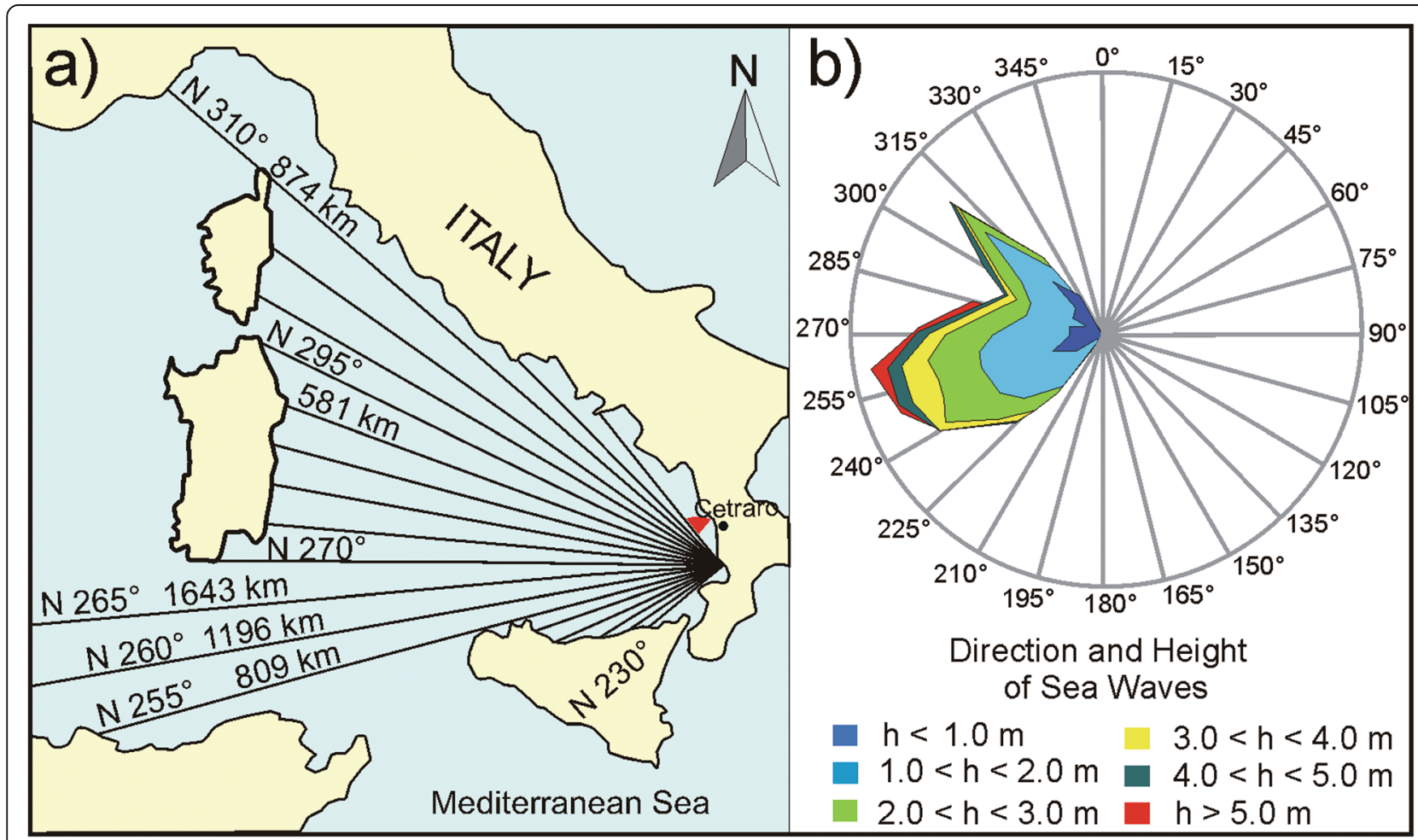

Fig. 2 a Wave fetch window in the study area; red triangle shows the location of the Cetraro buoy; $\mathbf{b}$ Wave height and mean wave direction obtained by the Cetraro buoy during the period 2004-2007 
characterized by a width of $10 \mathrm{~km}$ (Mongardi et al. 2004). In this area, the subtidal profile, within the isobath of $-5 \mathrm{~m}$, shows a low gradient equal to $2 \%-4 \%$ (Lupia Palmieri and Raffi 1983). Diving observations allowed recognizing subtidal bar deposition at the $-9 \mathrm{~m}$ isobath, where the seabed depth sharply decreases to $-6 \mathrm{~m}$. Coastal-lake and lagoons are present in the backshore area, and the frequent formation and destruction of spit forms show the occurrence of geomorphological cyclic processes (Ietto et al. 2012a). Relatively stable beachdune ridges (1.0-1.5 $\mathrm{m}$ in height), covered by natural vegetation type of Mediterranean macchia (e.g. SorrisoValvo 1997), are present at the storm swash limit of the backshore zone. The subaerial beaches show a low topographic gradient with a convex profile and their width ranges from $70 \mathrm{~m}$ to $170 \mathrm{~m}$.

Savuto and Amato rivers are the main drainage systems (Fig. 1b), both lacking a deltaic cusp system, because the strong wave processes distribute the whole sediment load along the coastline (e.g. Hoitink and Jay 2016). The Angitola River and other minor torrentialtype streams contribute to the clastic sediment supply in this coastal area (Le Pera and Critelli 1997). The littoral drift is oriented towards south on the northern side of the study area, whereas a littoral drift oriented towards north dominates on the southernmost littoral area up to the Angitola river-mouth (Lupia Palmieri and Raffi 1983; D'Alessandro et al. 1992; Le Pera and Critelli 1997) (Fig. 1b). The littoral drift regime seems to influence the mouths of both rivers and streams in the study area as well. Indeed, geomorphological observations point out that all mouths of the drainage systems from the Amato River towards south are mainly oriented towards north; on the contrary, on the northern side, the river- and stream-mouths are oriented towards the south.

\section{Methodology}

\subsection{Determination of shoreline change}

The beach is defined as the area stretching from the dune crest to the closure depth (e.g. Masselink and Short 1993; Van Rijn et al. 2003; Krause and Soares 2004), and it includes the shoreline that represents the physical interface between land and sea-water (Dolan et al. 1980; Boak and Turner 2005). The historical analysis of the shoreline changes was performed through the comparison of topographic maps, orthophotos, Differential Global Position System (DGPS) data and Google Earth satellite images, which allowed delineating the shoreline position change between the year 1870 and year 2019. In particular, the topographic maps of the Italian "Istituto Geografico Militare" (IGM) were used for interpreting the historical reconstruction of the shoreline changes during the periods of 1870-1954, 1954-1983 and 1983-1990. Shoreline positions for the years 1996 and 2000 were obtained from orthophoto data, whereas for the years 2005, 2010 and 2019 Google Earth satellite images were used. Finally, the shoreline position of the year 2009 was detected by DGPS survey (Fig. 3). The shoreline locations in orthophotos and satellite images were recognized on the basis of a visual interpretation of colour or grey scale differences (light blue: sea and light yellow: beach; or, dark grey: sea and light grey: beach), according to the method suggested by Demirpolat and Tanner (1991) and Boak and Turner (2005); instead, the shoreline position in the topographic maps was detected through the dark line between land and sea (Boak and Turner 2005). For the shoreline identification, we did not consider sea-level fluctuations related to tides of astronomical origin, because they are highly dependent on the topography of the marine basin (e.g. Ferrarin et al. 2013; Cutroneo et al. 2017). Indeed, along the steep seabed of the Calabria Tyrrhenian coast the sea-level fluctuations are very low and can be negligible (e.g. Morucci et al. 2016). These data were analyzed and managed into a Geographic Information System (GIS), in particular the ESRI (Environmental System Research Institute) ArcGIS 10.1 software, which was employed to determine both the geomorphological evolution of the beaches and the quantitative changes. For this purpose, not less than four ground control-points were chosen to ensure acceptable data in each process step; so, the data sets showed a total maximum shoreline position error of $\pm 6.0 \mathrm{~m}$.

\subsection{Beach sediment sampling and analytical method}

Thirty sediment samples were collected in the shoreface and backshore zones, along respectively three and seven transects (Table 1 and Fig. 4), to arrive at a detailed petrographic characterization of the emerged and submerged beach environment.

The modern sand composition is strongly dependent on the sampling scale. Three different sampling groups, i.e., first-order, second-order and third-order sand samples, were defined (e.g. Ingersoll 1990). First-order sands, sampled from talus piles and local drainages, are little or not modified by weathering, thus providing direct information on the source rock. Second-order sands are those collected from rivers draining large areas; therefore, their composition reflects modification by climate, relief and transport. Third-order sands are from big rivers and deltas and can provide information on continental-scale petrofacies distribution (Dickinson 1988; Ingersoll et al. 1993; Critelli et al. 1997, 2003). The sediment samples were collected from shoreface and backshore zones, spaced along the stretch of coast between the rocky headland of Capo Suvero and the long beach of Gizzeria Lido (Fig. 4). Therefore, they are considered as second-order sand samples according to 


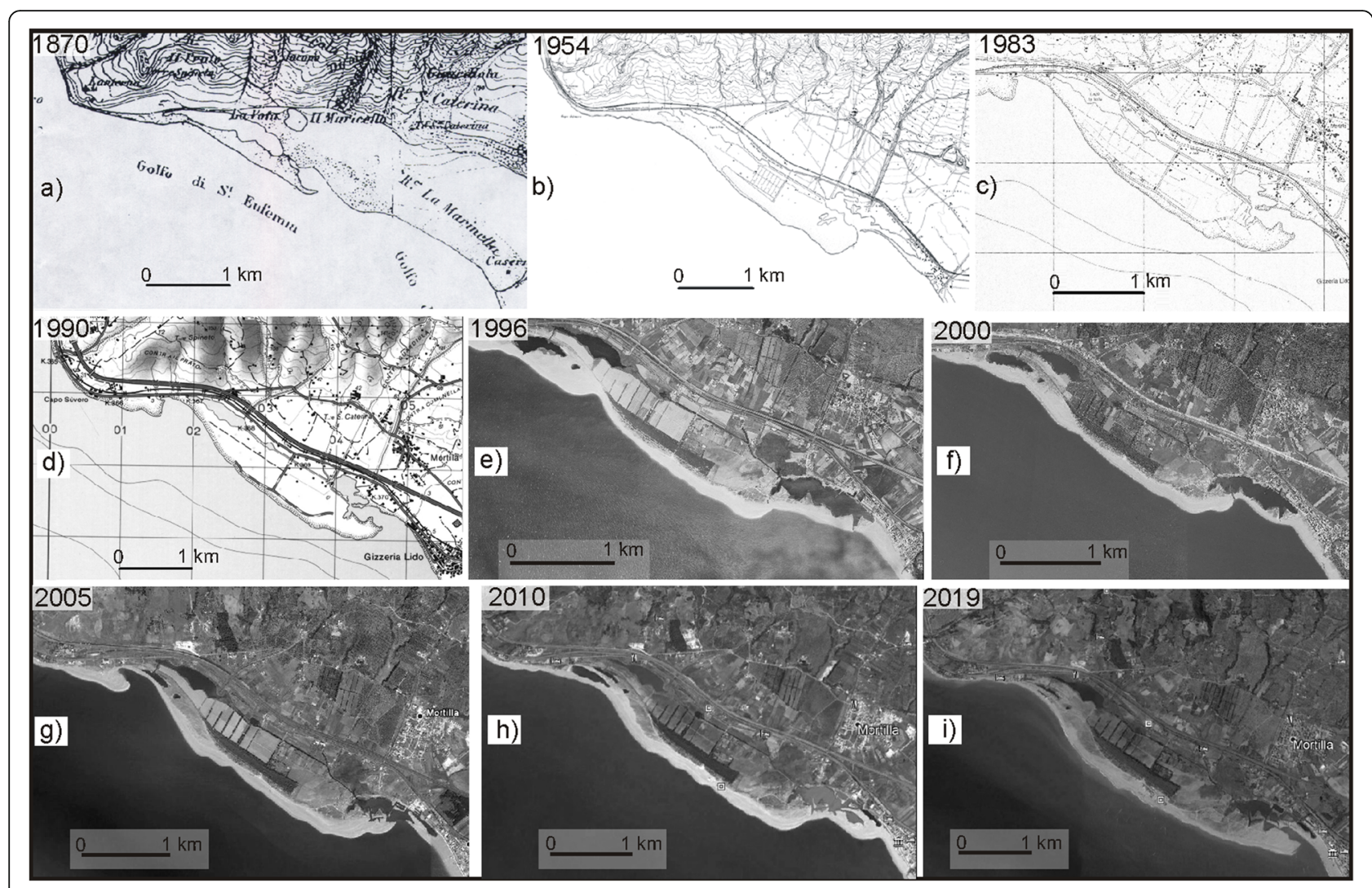

Fig. 3 Material used for the reconstruction of the geomorphological evolution of the beaches. a-d Cartographic maps; e-f Orthophotos; $\mathbf{g}-\mathbf{i}$ Satellite images

Table 1 Geographic position of sediment samples collected in shoreface and backshore sub-environments

\begin{tabular}{|c|c|c|c|c|}
\hline $\begin{array}{l}\text { Shoreface samples } \\
\text { (refer to Fig. } 4 \text { for position) }\end{array}$ & Depth (m) & Geographic position & $\begin{array}{l}\text { Backshore samples } \\
\text { (refer to Fig. } 4 \text { for position) }\end{array}$ & Geographic position \\
\hline 1 & -5 & $\begin{array}{l}\mathrm{N} 38^{\circ} 56^{\prime} 45^{\prime \prime} \\
\mathrm{E} 16^{\circ} 10^{\prime} 07^{\prime \prime}\end{array}$ & $\begin{array}{l}\text { Transect } 1 \\
\text { (from } 11 \text { to 16) }\end{array}$ & $\begin{array}{l}\text { N38 } 38^{\circ} 56^{\prime} 54^{\prime \prime} \\
\text { E16 } 16^{\circ} 14^{\prime \prime}\end{array}$ \\
\hline 2 & -9 & $\begin{array}{l}\mathrm{N} 38^{\circ} 56^{\prime} 40^{\prime \prime} \\
\mathrm{E} 16^{\circ} 09^{\prime} 53^{\prime \prime}\end{array}$ & $\begin{array}{l}\text { Transect } 2 \\
(17,18)\end{array}$ & $\begin{array}{l}\mathrm{N} 38^{\circ} 56^{\prime} 40^{\prime \prime} \\
\mathrm{E} 16^{\circ} 10^{\prime} 38^{\prime \prime}\end{array}$ \\
\hline 3 & -7 & $\begin{array}{l}\text { N38 } 56^{\circ} 44^{\prime \prime} \\
\text { E16 } 09^{\circ} 54^{\prime \prime}\end{array}$ & $\begin{array}{l}\text { Transect } 3 \\
\text { (from } 19 \text { to 23) }\end{array}$ & $\begin{array}{l}\mathrm{N} 38^{\circ} 56^{\prime} 23^{\prime \prime} \\
\mathrm{E} 16^{\circ} 10^{\prime} 57^{\prime \prime}\end{array}$ \\
\hline 4 & -10 & $\begin{array}{l}\mathrm{N} 38^{\circ} 56^{\prime} 24^{\prime \prime} \\
\mathrm{E} 16^{\circ} 09^{\prime} 46^{\prime \prime}\end{array}$ & $\begin{array}{l}\text { Transect } 4 \\
(24,25)\end{array}$ & $\begin{array}{l}\text { N38 } 38^{\circ} 56^{\prime} 10^{\prime \prime} \\
\text { E16 } 16^{\circ} 17^{\prime \prime}\end{array}$ \\
\hline 5 & -20 & $\begin{array}{l}\mathrm{N} 38^{\circ} 56^{\prime} 18^{\prime \prime} \\
\mathrm{E} 16^{\circ} 09^{\prime} 40^{\prime \prime}\end{array}$ & $\begin{array}{l}\text { Transect } 5 \\
(26,27)\end{array}$ & $\begin{array}{l}\text { N38 } 38^{\circ} 55^{\prime} 59^{\prime \prime} \\
\text { E16 } 11^{\circ} 44^{\prime \prime}\end{array}$ \\
\hline 6 & -10 & $\begin{array}{l}\text { N38 } 55^{\circ} 52^{\prime \prime} \\
\text { E16 } 11^{\circ} 11^{\prime} 19^{\prime \prime}\end{array}$ & $\begin{array}{l}\text { Transect } 6 \\
(28,29)\end{array}$ & $\begin{array}{l}\text { N38 } 38^{\circ} 55^{\prime} 53^{\prime \prime} \\
\text { E16 } 16^{\circ} 07^{\prime \prime}\end{array}$ \\
\hline 7 & -20 & $\begin{array}{l}\mathrm{N} 38^{\circ} 55^{\prime} 49^{\prime \prime} \\
\mathrm{E} 16^{\circ} 11^{\prime} 18^{\prime \prime}\end{array}$ & $\begin{array}{l}\text { Transect } 7 \\
\text { (30) }\end{array}$ & $\begin{array}{l}\mathrm{N} 38^{\circ} 55^{\prime} 52^{\prime \prime} \\
\mathrm{E} 16^{\circ} 12^{\prime} 39^{\prime \prime}\end{array}$ \\
\hline 8 & -5 & $\begin{array}{l}\mathrm{N} 38^{\circ} 55^{\prime} 52^{\prime \prime} \\
\mathrm{E} 16^{\circ} 12^{\prime} 13^{\prime \prime}\end{array}$ & & \\
\hline 9 & -9 & $\begin{array}{l}\mathrm{N} 38^{\circ} 55^{\prime} 38^{\prime \prime} \\
\mathrm{E} 16^{\circ} 12^{\prime} 12^{\prime \prime}\end{array}$ & & \\
\hline 10 & -10 & $\begin{array}{l}\mathrm{N} 38^{\circ} 55^{\prime} 22^{\prime \prime} \\
\mathrm{E} 16^{\circ} 12^{\prime} 00^{\prime \prime}\end{array}$ & & \\
\hline
\end{tabular}




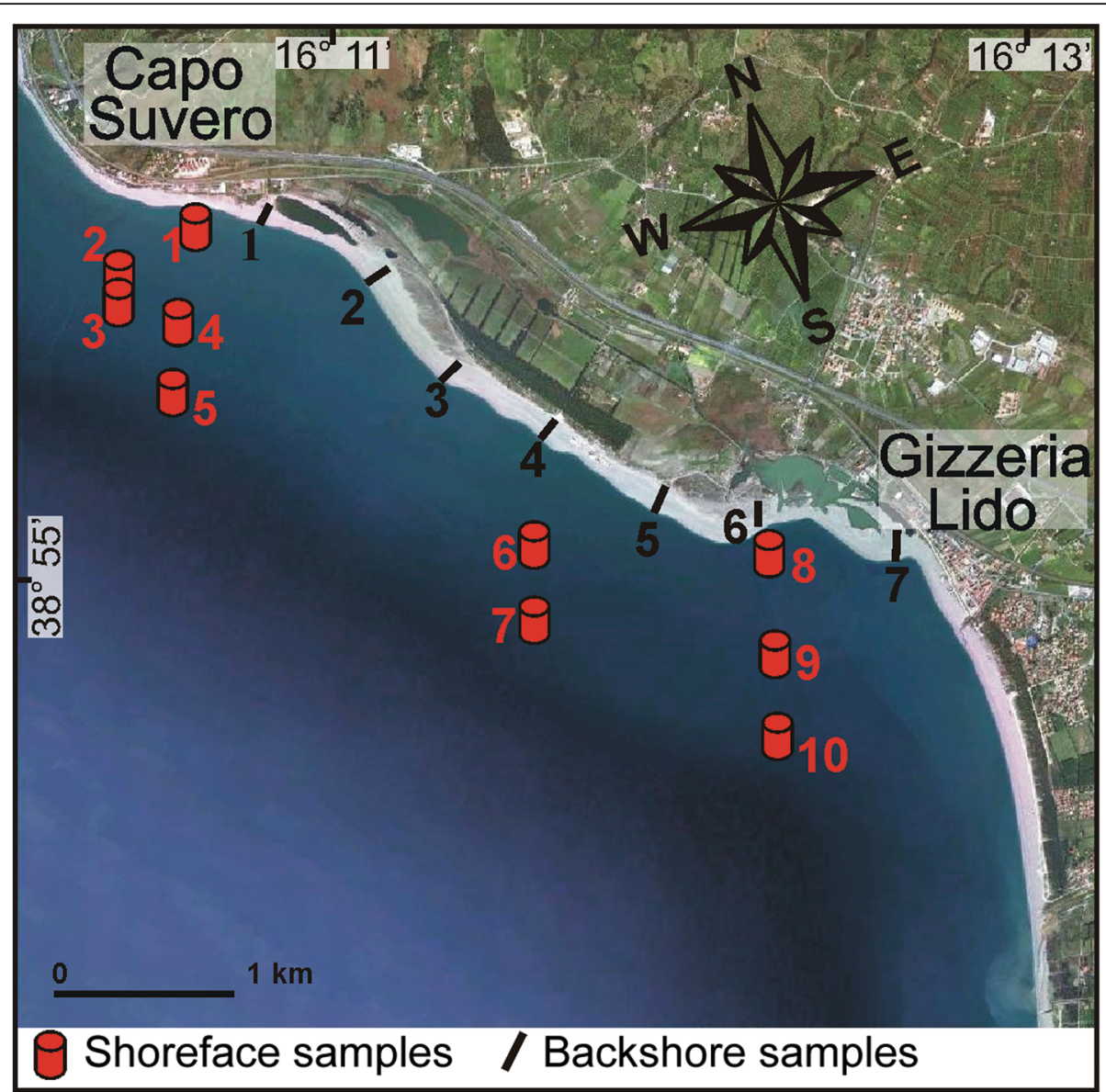

Fig. 4 Shoreface and backshore sampling positions between Capo Suvero and Gizzeria Lido (for geographic data of samples see Table 1)

Ingersoll (1990). Twenty backshore samples were collected along seven transects (equally spaced), between the swash zone and the high berm crest; ten shoreface samples were collected along three transects normal to the shoreline, between the $-5 \mathrm{~m}$ and $-20 \mathrm{~m}$ isobaths, using a grab sampler (Table 1 and Fig. 4). We compared petrographic features of our samples with the Amato and Savuto rivers in order to investigate the provenance. The petrographic data of the Amato and Savuto rivers were obtained from the literature (Le Pera and Critelli 1997; Le Pera and Sorriso-Valvo 2000b; Le Pera et al. 2000; Critelli and Le Pera 2003).

All beach sediment-samples were washed using $\mathrm{H}_{2} \mathrm{O}_{2}$ to remove clays and organic matter, air-dried and sieved in order to obtain the grain-size distribution (using 1 interval, Table 2, Fig. 5). The $0.25-0.50 \mathrm{~mm}$ size fraction was selected to prepare thin sections that were analyzed for petrographic composition of the medium sand. Each thin section was etched and stained using HF and sodium cobaltinitrite for feldspar grain identification. At least 246 and a maximum of 402 grains for each thin section were counted using the Gazzi-Dickinson pointcounting method (Ingersoll et al. 1984; Zuffa 1985).

In the present research, the QFL (e.g. Dickinson and Suczek 1979) and $R_{g} R_{s} R_{m}$ plots (Critelli and Le Pera 1994, 1995) were used to determine the possible compositional variability between backshore and shoreface environments, and the influence of source rock lithotypes and of local coastal drainages on sand composition; and to compare processes acting on the backshore area and on shallow-marine sedimentation of the shoreface. Other than the QFL diagram approach (e.g. Dickinson and Suczek 1979), the $R_{g} R_{s} R_{m}$ plot, more useful in combining phaneritic rock (grains having crystals > $0.0625 \mathrm{~mm}$ ) and aphanitic lithic fragments (grains having crystals $<0.0625 \mathrm{~mm}$ ), allows to evaluate all information derived from point counts of medium-grained sand (e.g. Critelli and Le Pera 1994). This type of plot is particularly useful for the sampled sand because: (1) schist, phyllite, gneiss and sedimentary rocks comprise about $90 \%$ of the bedrock lithology; (2) there are diverse proportions of these rock types within drainages of this 
Table 2 Grain-size distribution of the ten shoreface samples and 20 backshore samples. Values are expressed in \%

\begin{tabular}{|c|c|c|c|c|c|c|c|}
\hline \multicolumn{8}{|c|}{ Shoreface samples } \\
\hline Sample No. & Vc & $\mathrm{C}$ & M & $\mathrm{F}$ & Vf & $\mathrm{S} / \mathrm{C}$ & Sample Type/Name \\
\hline 1 & 0.6 & 3.4 & 18.1 & 63.3 & 13.4 & 1.2 & Unimodal, moderately-sorted fine sand \\
\hline 2 & 4.2 & 47.8 & 45.2 & 2.4 & 0.4 & 0.0 & Unimodal, well-sorted coarse sand \\
\hline 3 & 0.2 & 1.4 & 15.4 & 49.4 & 30.6 & 3.0 & Unimodal, moderately-sorted fine sand \\
\hline 4 & 0.6 & 12.1 & 59.2 & 27.0 & 1.1 & 0.0 & Unimodal, moderately-sorted medium sand \\
\hline 5 & 0.3 & 0.7 & 17.3 & 63.1 & 16.4 & 2.2 & Unimodal, moderately-sorted fine sand \\
\hline 6 & 1.5 & 35.5 & 57.3 & 5.6 & 0.1 & 0.0 & Unimodal, moderately-sorted medium sand \\
\hline 7 & 0.2 & 7.4 & 31.1 & 54.7 & 6.6 & 0.0 & Unimodal, moderately-sorted fine sand \\
\hline 8 & 91.5 & 2.0 & 2.9 & 3.4 & 0.2 & 0.0 & Unimodal, moderately-sorted very coarse sand \\
\hline 9 & 13.1 & 59.1 & 26.4 & 1.4 & 0.0 & 0.0 & Unimodal, moderately-sorted coarse sand \\
\hline 10 & 0.3 & 8.1 & 22.1 & 53.3 & 15.6 & 0.6 & Unimodal, moderately-sorted fine sand \\
\hline \multicolumn{8}{|c|}{ Backshore samples } \\
\hline Sample No. & Vc & $\mathrm{C}$ & M & $\mathbf{F}$ & Vf & $S / C$ & Sample Type/Name \\
\hline 11 & 30.6 & 47.4 & 20.2 & 1.8 & 0.0 & 0.0 & Unimodal, moderately-sorted coarse sand \\
\hline 12 & 5.6 & 79.1 & 14.9 & 0.3 & 0.1 & 0.0 & Unimodal, well-sorted coarse sand \\
\hline 13 & 11.9 & 75.9 & 11.2 & 0.6 & 0.4 & 0.0 & Unimodal, moderately-sorted coarse sand \\
\hline 14 & 22.6 & 66.4 & 9.5 & 0.3 & 0.1 & 1.1 & Unimodal, moderately-sorted coarse sand \\
\hline 15 & 64.1 & 31.2 & 4.3 & 0.3 & 0.1 & 0.0 & Unimodal, moderately-sorted very coarse sand \\
\hline 16 & 40.9 & 39.2 & 15.2 & 4.5 & 0.2 & 0.0 & Unimodal, moderately-sorted very coarse sand \\
\hline 17 & 9.3 & 78.9 & 11.7 & 0.1 & 0.0 & 0.0 & Unimodal, well-sorted coarse sand \\
\hline 18 & 25.5 & 68.5 & 6.0 & 0.0 & 0.0 & 0.0 & Unimodal, well-sorted coarse sand \\
\hline 19 & 14.6 & 76.4 & 8.8 & 0.1 & 0.1 & 0.0 & Unimodal, well-sorted coarse sand \\
\hline 20 & 19.7 & 74.1 & 6.1 & 0.1 & 0.0 & 0.0 & Unimodal, well-sorted coarse sand \\
\hline 21 & 19.3 & 72.0 & 8.4 & 0.3 & 0.0 & 0.0 & Unimodal, well-sorted coarse sand \\
\hline 22 & 14.0 & 79.9 & 6.0 & 0.1 & 0.0 & 0.0 & Unimodal, well-sorted coarse sand \\
\hline 23 & 51.8 & 43.8 & 4.2 & 0.2 & 0.0 & 0.0 & Unimodal, moderately-sorted very coarse sand \\
\hline 24 & 0.7 & 77.1 & 16.7 & 5.4 & 0.1 & 0.0 & Unimodal, well-sorted coarse sand \\
\hline 25 & 8.0 & 83.6 & 8.0 & 0.4 & 0.0 & 0.0 & Unimodal, well-sorted coarse sand \\
\hline 26 & 14.7 & 75.2 & 9.5 & 0.6 & 0.0 & 0.0 & Unimodal, well-sorted coarse sand \\
\hline 27 & 71.8 & 27.1 & 1.1 & 0.0 & 0.0 & 0.0 & Unimodal, well-sorted very coarse sand \\
\hline 28 & 24.4 & 70.4 & 5.2 & 0.0 & 0.0 & 0.0 & Unimodal, well-sorted coarse sand \\
\hline 29 & 64.6 & 33.9 & 1.4 & 0.1 & 0.0 & 0.0 & Unimodal, well-sorted very coarse sand \\
\hline 30 & 49.7 & 39.6 & 9.8 & 0.9 & 0.0 & 0.0 & Unimodal, moderately-sorted very coarse sand \\
\hline
\end{tabular}

VC Very coarse sand; C Coarse sand; $M$ Medium sand; $F$ Fine sand; Vf Very fine sand; S/C Silt and clay

coastal petrological sedimentary province; (3) it is easy to recalculate both phaneritic and aphanitic rock/lithic types using the Gazzi-Dickinson point-counting method (e.g. Critelli and Le Pera 1994; Critelli and Ingersoll 1995).

\section{Results}

4.1 Shoreline evolution

The comparison of ancient and modern shoreline positions, respectively corresponding to years 1870 and 2019 , allowed the identification of a geomorphological accretion trend in the study area (Fig. 6). The comparison showed a maximum linear progradation of $900 \mathrm{~m}$, corresponding to an average rate of $+6.5 \mathrm{~m} / \mathrm{yr}$ in the beach located at the north side of Gizzeria Lido. In the same period, the minimum linear progradation of $400 \mathrm{~m}$, equivalent to an average rate of about $+3 \mathrm{~m} / \mathrm{yr}$, was recorded close to La Vota Lake. During the analyzed period, cyclic formation and dismantling processes of spits at the "La Vota" and "Maricello" localities occurred. In particular, the detailed historical geomorphological study highlights that a significant coastal progradation 

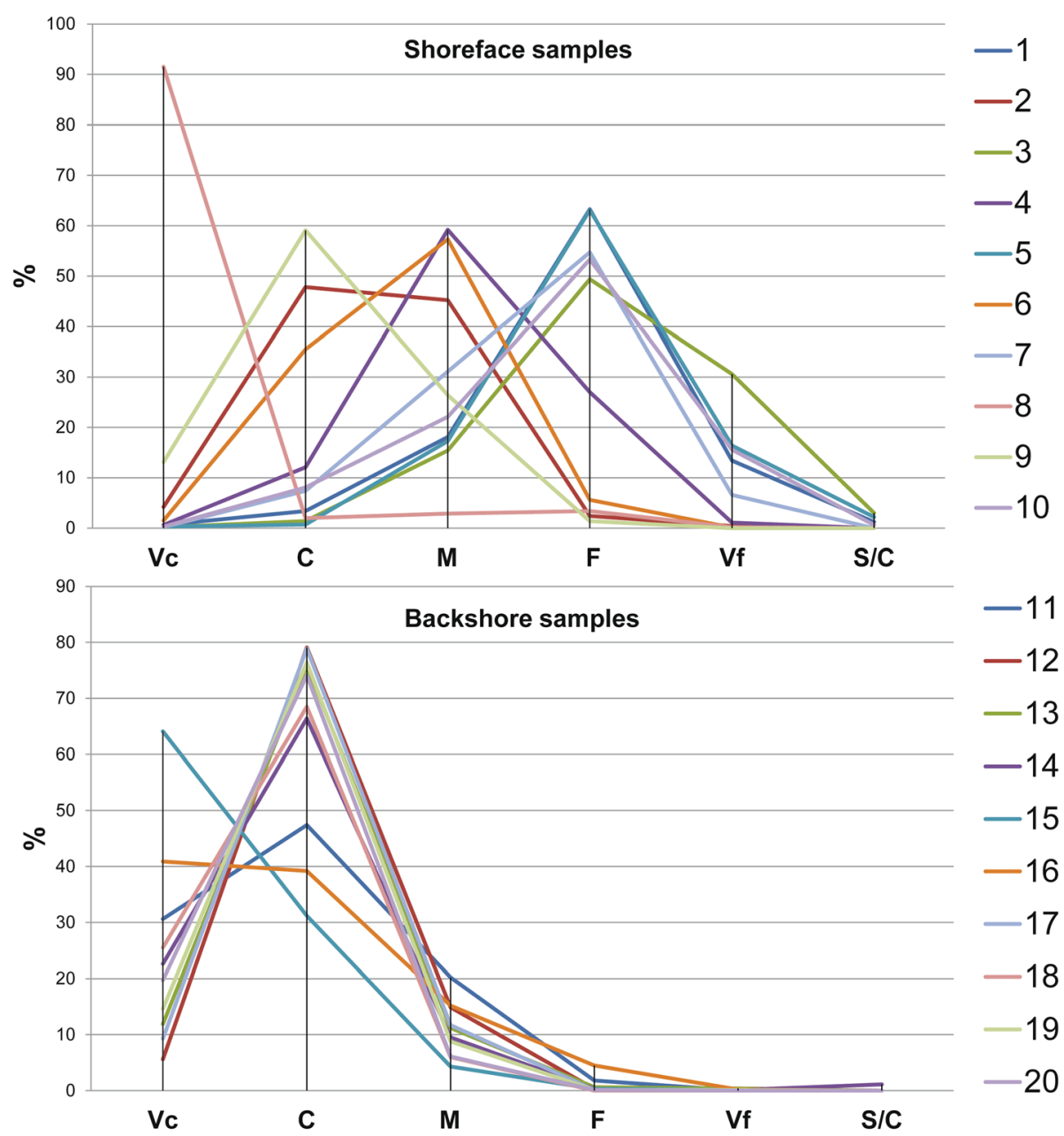

$-13$

$-14$

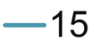

$-16$

$-17$

$-18$

$-19$

$-20$

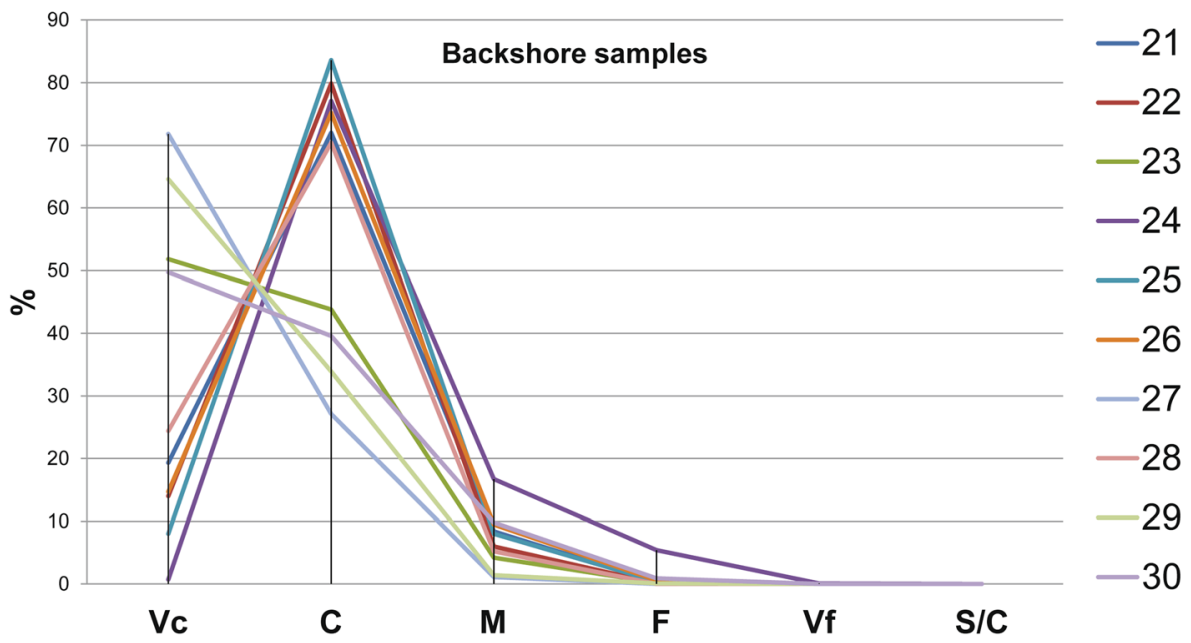

Fig. 5 Grain-size distribution diagram for the 30 analyzed samples (see with Table 2). The grain size differentiation is shown on the $x$-axis (Vc: Very coarse sand; C: Coarse sand; M: Medium sand; F: Fine sand; Vf: Very fine sand; S/C: Silt and clay). The proportion (\%) is shown on the $y$-axis

caused the formation of a spit, with a northward directed growth, close to the Maricello locality during 1870-1954. The years 1954 to 1983 were characterized by intensive erosion processes, which produced a dismantling of the previous spit and the formation of a new 320-m-wide subaerial sandbar, with a southward 


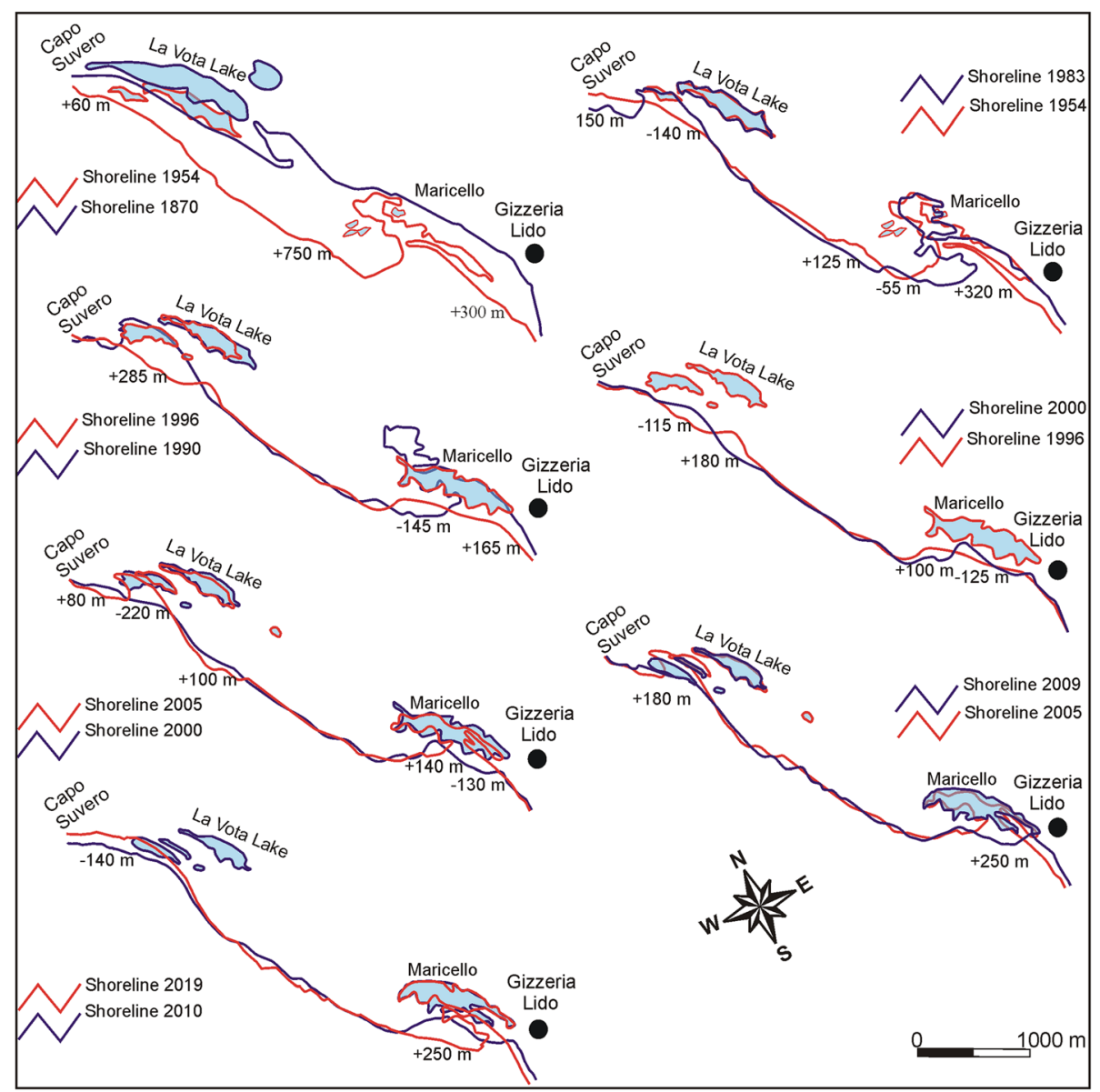

Fig. 6 Shoreline evolution between 1870 and 2019. The following maximum progradation or erosion were observed during the examined period: $+750 \mathrm{~m}$ between 1870 and 1954; $320 \mathrm{~m}$ and $-140 \mathrm{~m}$ between 1954 and 1983; $+285 \mathrm{~m}$ and $-145 \mathrm{~m}$ between 1990 and $1996 ;+180 \mathrm{~m}$ and $-125 \mathrm{~m}$ between 1996 and 2000; $+140 \mathrm{~m}$ and $-220 \mathrm{~m}$ between 2000 and 2005; $+250 \mathrm{~m}$ between 2005 and $2009 ;+250 \mathrm{~m}$ and $-140 \mathrm{~m}$ between 2010 and 2019

directed growth in Maricello area. Between 1983 and 1990, the littoral area showed no significant changes. The period of 1990-1996 was dominated by an extensive growth of the Maricello sandbar towards the south, causing closure of the inlet and formation of a coastal lake. The same process occurred in the La Vota area, where a new lake was formed. In the same period, other shoreline changes occurred with maximum accretion rates equal to $+285 \mathrm{~m}$ at the Maricello beach (average rate of $+47 \mathrm{~m} / \mathrm{yr}$ ) and equal to $+165 \mathrm{~m}$ at the Gizzeria Lido beach (average rate of $+27 \mathrm{~m} / \mathrm{yr}$ ). From 1996 to 2000 , widespread erosion and accretion stages were observed between the Maricello and Gizzeria Lido beach. Between 2000 and 2005, a new shoreline change occurred at the La Vota and Maricello localities and two new spits began to form with a south-directed growth. The inlet closure of two new spits occurred during 2005-2009, with formation of new coastal lakes. Finally, the period of 2010-2019 was characterized by new shoreline changes, consisting of erosional processes near La Vota Lake (up to $-140 \mathrm{~m}$ ) and accretionary processes in the Maricello beach area (up to $+240 \mathrm{~m}$ ).

\subsection{Relationship between grain size and sand composition}

Shoreface and backshore sediment samples display an unimodal grain-size distribution, dominated by the sand fraction (Table 2; Fig. 5). The shoreface samples, collected at different water depths, exhibit different peaks among the grain-size fraction (very coarse, coarse, medium and fine); whereas among the backshore samples, the majority contain more than $60 \%$ (in weight) of the coarse sand fraction (Table 2; Fig. 5). As a result of their unimodality, samples are moderately- to wellsorted (Table 2). By comparing the relative abundance of single crystal grains (SC) and rock fragments (RF) between shoreface and backshore samples (medium sand fraction) (Fig. 7), it is evident that single crystals always 

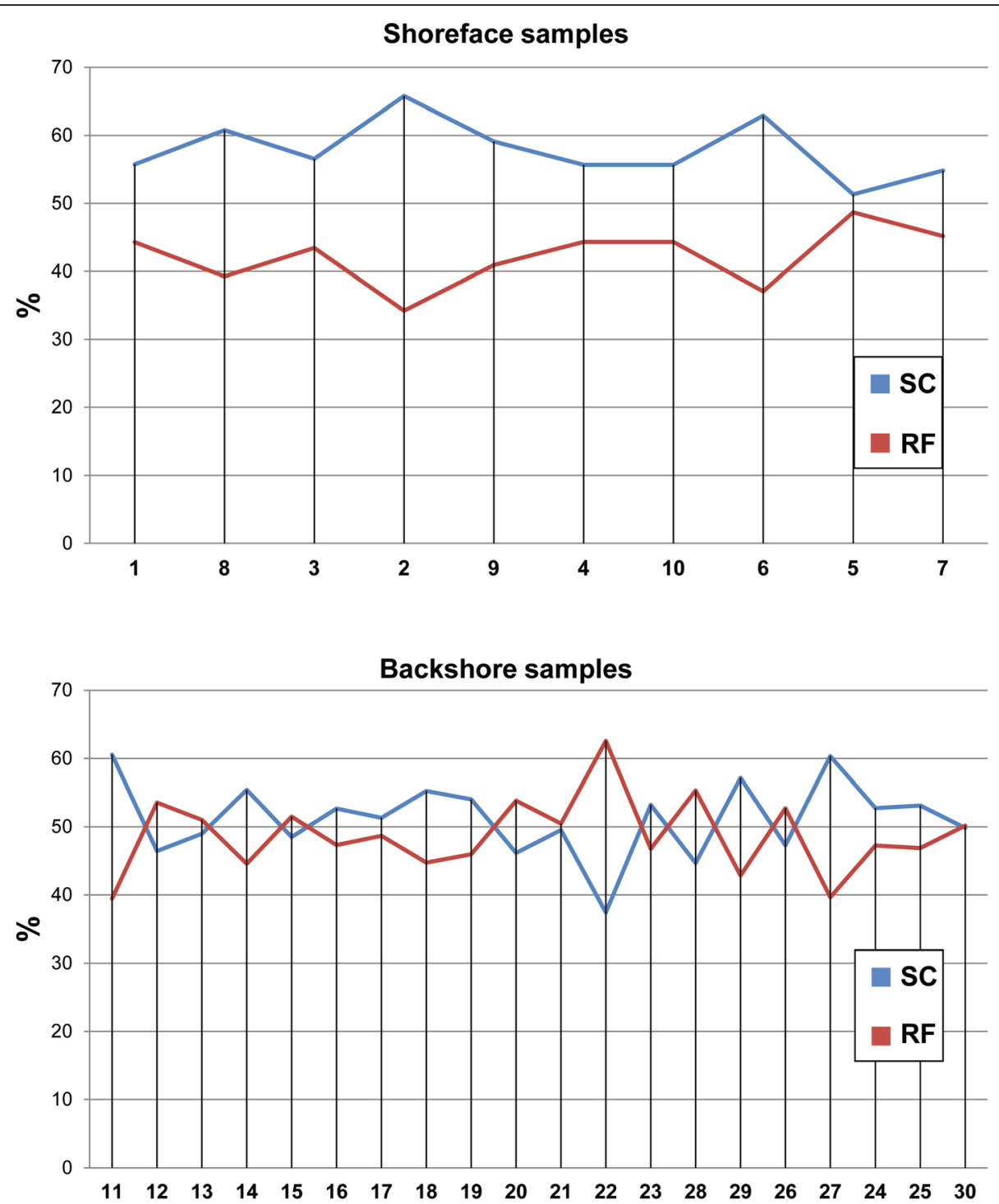

Fig. 7 Diagram showing the relative abundance of single crystals versus composite rock fragments (both phaneritic rock fragments and aphanitic lithics) in shoreface and backshore samples. The shoreface samples are ordered by depth (from the $-5 \mathrm{~m}$ isobath to the $-20 \mathrm{~m}$ isobath), whereas the backshore samples are grouped from north to south along the studied coastal stretch (from Capo Suvero to Gizzeria Lido). The sample numbers/names are shown on the x-axis; the contents (expressed in \%) of single crystals (SC) and rock fragments (RF) are shown on the $y$-axis

account for a higher percentage than rock fragments in the shoreface environment; whereas in the backshore environment, single crystals show a trend that several times crosses that of rock fragments. This trend highlights a variable content in both grain types (Fig. 7) and thus suggests a lower degree of textural maturity of the backshore samples with respect to the shoreface ones. Moreover, the shoreface samples are grouped by depth (from the $-5 \mathrm{~m}$ isobath to the $-20 \mathrm{~m}$ isobath; see Table 2), demonstrating that there is no correlation between depth and the content of single crystals/rock fragments.

\subsection{Grain types}

Metamorphic rock fragments are the dominant grain type in both sands from backshore and shoreface environments $(68 \%$ and $32 \%$, respectively; Fig. 8 and Additional file 1). Quartz occurs both as polycrystalline and monocrystalline grains. Polycrystalline quartz grains with tectonic fabric prevail over polycrystalline grains without tectonic fabric for both backshore and shoreface sands. K-feldspar and plagioclase dominantly occur as single grains, and are less common in both aphanitic lithics and phaneritic rock fragments. Phaneritic rock fragments are granitoid in composition (gneissic percentage 


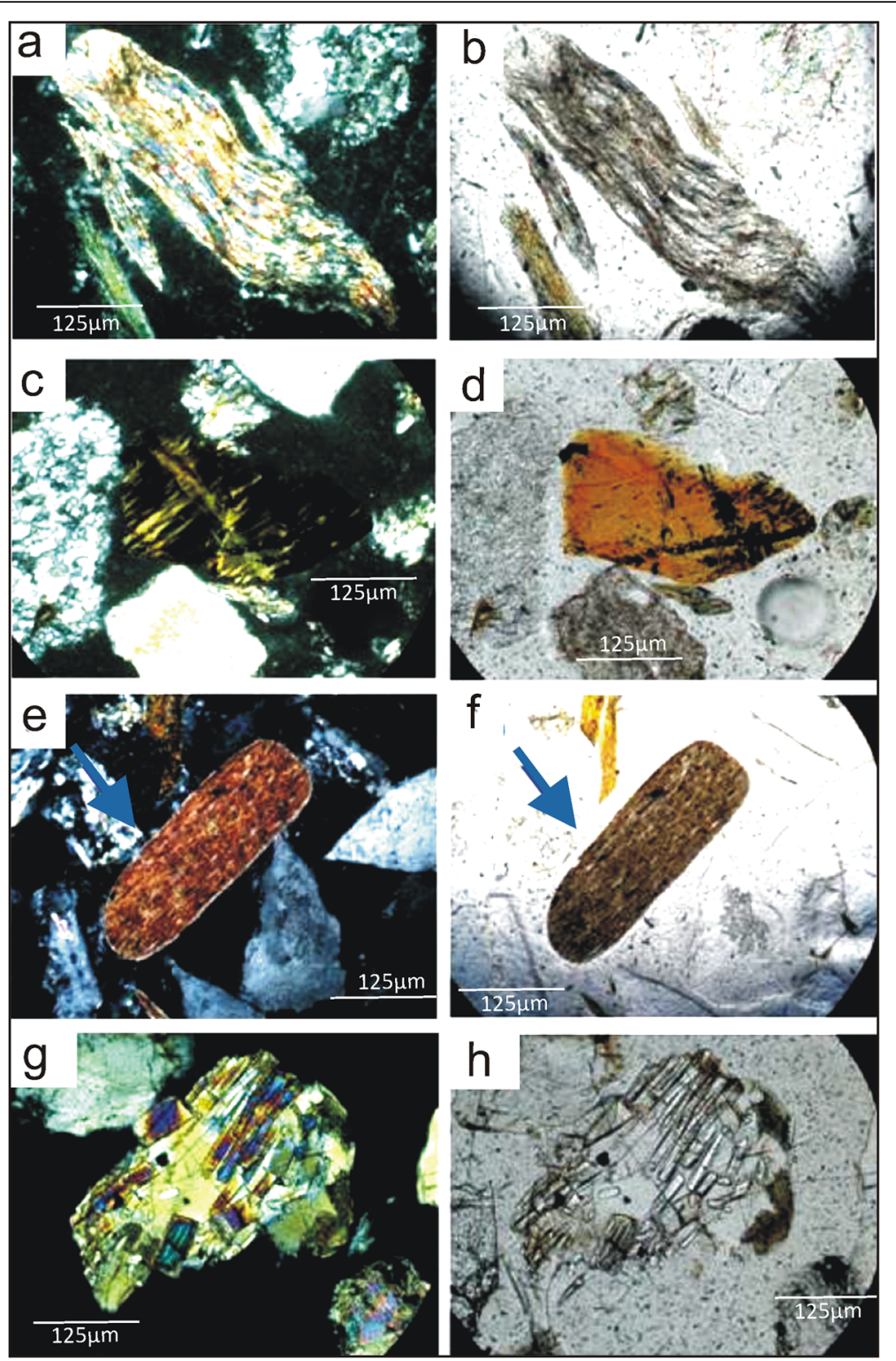

Fig. 8 Photomicrographs of metamorphic grains within the modern beach sand of the studied coastline. $\mathbf{a}-\mathbf{b}$ Phyllite grain; $\mathbf{c}-\mathbf{d}$ Serpentinite grain; e-f Shale grain; $\mathbf{g - h}$ Sillimanite grain. $\mathbf{a}, \mathbf{c}, \mathbf{e}, \mathbf{g}$ - Cross-polarized light; $\mathbf{b}, \mathbf{d}, \mathbf{f}, \mathbf{h}$ - Plane-polarized light

is greater than granitic percentage) and are composed of quartz+feldspar and quartz+feldspar+mica or quartz+ feldspar+dense mineral (especially opaque minerals, e.g. Le Pera and Morrone 2018) aggregates (Fig. 8). Aphanitic lithic fragments are fine-grained and are made up of schist, concentrated in both backshore and shoreface sands; phyllite grains are a minor component and shale+ slate+serpentinite lithic grains also occur in both sedimentary environments. Muscovite, biotite and chlorite, occurring as single grains, are quite similar in percentage, even if, in metamorphic rock fragments, the chlorite is the most common phyllosilicate in both backshore and shoreface sands. The highest percentage of opaque grains is found in the backshore sand samples and, on the average, their concentration is three times higher than in the shoreface sand samples. A very high concentration of ilmenite and magnetite grains in shoreface sands from the $-5 \mathrm{~m}$ and $-20 \mathrm{~m}$ isobaths, closest to the Angitola river-mouth, has been reported by Brondi et al. (1972). These authors argued that the detrital opaque grains compare closely with the opaque grains from source rocks composed of garnet-sillimanite gneiss (e.g. Amodio-Morelli et al. 1976), exposed in the Angitola River catchment (Fig. 1). According to the pointcounting method, the petrographic grain categories are tabulated in Additional file 1. 


\subsection{Modal composition}

The average modal abundance of each grain type was calculated from point counts of samples collected from backshore and shoreface environments (Table 1). The RgRsRm plot (Fig. 9), well suited for illustrating data of sands derived from mid-crustal rocks and for discriminating the main sedimentary petrologic provinces (e.g. Critelli and Le Pera 1994; Le Pera et al. 2001; Caracciolo et al. 2011, 2012; Morrone et al. 2017, 2020; Chaudhuri et al. 2018), combines the relative proportion of phaneritic rock fragments and aphanitic lithics. Specifically, $\mathrm{Rg}$ (granitoid rock fragments) comprises plutonic phaneritic rock fragments and gneissic rock fragments; Rs (sedimentary rock fragments) comprises phaneritic rock fragments and aphanitic lithics of both siliciclastic and carbonate sedimentary rocks; Rm (metamorphic rock fragments) comprises metamorphic phaneritic rock fragments and aphanitic lithics such as schist+phyllite+serpentinite. Moreover, we use the terms (1) schistphylliticlastic sand for a sand in which schistose and phyllitic detritus is predominant; (2) gneissiclastic sand for a sand in which gneissose detritus is predominant; (3) plutoniclastic sand for a sand having only plutonic detritus or in which plutonic detritus is predominant (e.g. Critelli and Le Pera 2003). QFL plot (e.g. Dickinson and Suczek 1979) is used to show a possible compositional differentiation between the two sub-environments of the studied coastal domain (Fig. 10).

Using $R_{g} R_{s} R_{m}$ and QFL plots discriminated only one group of sand samples without any sharp separation between backshore and shoreface, and some overlap occurred between detrital modes (Figs. 9 and 10). The $R_{g} R_{s} R_{m}$ plot shows relative proportions of the granitic and gneissic rock fragments ( $R_{g}$ pole), the siliciclastic and carbonate sedimentary rock/lithic fragments $\left(R_{s}\right.$ pole), and the schist+phyllite+serpentinite rock/lithic fragments $\left(R_{m}\right.$ pole) (Fig. 9). Despite the clustering of data points close to the $\mathrm{L}$ apex, a small difference in sand composition can be observed as a slight shift towards the $\mathrm{Q}$ apex of some shoreface samples and a higher proportion of aphanitic lithic fragments $(\mathrm{L})$ in the backshore samples. This moderate shift of the compositional maturity trend in the QFL diagram (Fig. 10) suggests relatively short transport from backshore to shoreface environments of the studied coastal stretch (e.g. Le Pera et al. 2000). Therefore, backshore sands $\left(\% \mathrm{Rg}_{14} \mathrm{Rs}_{3} \mathrm{Rm}_{83} ; \quad \% \mathrm{Q}_{21} \mathrm{~F}_{22} \mathrm{~L}_{57}\right)$ and shoreface sands $\left(\% \mathrm{Rg}_{7} \mathrm{Rs}_{4} \mathrm{Rm}_{89} ; \% \mathrm{Q}_{31} \mathrm{~F}_{18} \mathrm{~L}_{51}\right)$ of the Capo Suvero-Gizzeria Lido beaches are lithic-rich (Figs. 9 and 10).

The analyzed samples show that schist-phylliticlastic grains including micaceous schist lithic fragments are predominant over phyllite lithic fragments in both backshore and shoreface environments (Figs. 9 and 10). Ultramaficlastic lithic grains, such as serpentinite lithic grains, are sporadic and more abundant in the shoreface than in the backshore environments. Siliciclastic rock fragments, mainly shale and fine-grained arenite, are very few in numbers, and their percentage in sand is undifferentiated between the backshore and the shoreface environments (Fig. 9). Calcite fragments as single crystals included among sedimentary lithics may suggest erosion from Tortonian to lower Pleistocene siliciclastic strata, or represent Quaternary shell fragments. Moreover, older source rocks (Upper Triassic-Lower Miocene), such as metalimestone and limestone, cannot be ruled out as other main suppliers to the sands.

Recalculated petrographic parameters used to construct the $R_{g} R_{s} R_{m}$ and QFL plots in Figs. 9 and 10 are listed in Additional file 2.

\section{Discussion}

Interpretation of modern siliciclastic sediment composition needs to take into account the control exerted by the source area and the effect of chemical weathering and transport processes (Johnsson 1993, and references therein). The detrital modes of the Capo Suvero-Gizzeria Lido sands indicate that the siliciclastic detritus was derived mostly from metamorphic source rock (schist+phyllite) lithotypes (Figs. 8, 9, 10). The spatial distribution of the schist-phylliticlastic rocks between the Capo Suvero promontory and Gizzeria Lido indicates sediment sourcing from the Savuto River that flows across the intermediate-lower crustal rocks of the Coastal Range domain (Coastal Range Littoral Province in Le Pera and Critelli 1997) characterized by a compound source association of schists, phyllites and minor garnet-sillimanite gneisses (e.g. Amodio-Morelli et al. 1976). Minor areal proportions of mafic to ultramafic oceanic source rocks, such as metabasites, serpentinites and amphibolites, are also exposed in the source area (e.g. Amodio-Morelli et al. 1976), yielding very low amounts of mafic to ultramafic lithic grains in the coastal sands. Serpentinite grains are more abundant in shoreface than in backshore sands and their occurrence indicates a clastic supply from the mafic to ultramafic oceanic source rocks of the Coastal Range. In the analyzed beach samples, the different abundance in metamorphiclastic sandy grains, ranked according to abundance, are schistose lithic fragments, phyllitic lithic fragments, gneissose rock fragments, and serpentinite. Each carries the signature of a distinct structural domain of the Coastal Range (e.g. Amodio-Morelli et al. 1976), and their abundance compares well with the exposure of metamorphic source lithotypes in the outcrop area.

Supply from the garnet-sillimanite-bearing gneiss terrane, although representing a lower areal exposure within the drainage basins in the study area, is testified in the quartzofeldspathic signature of the backshore and 

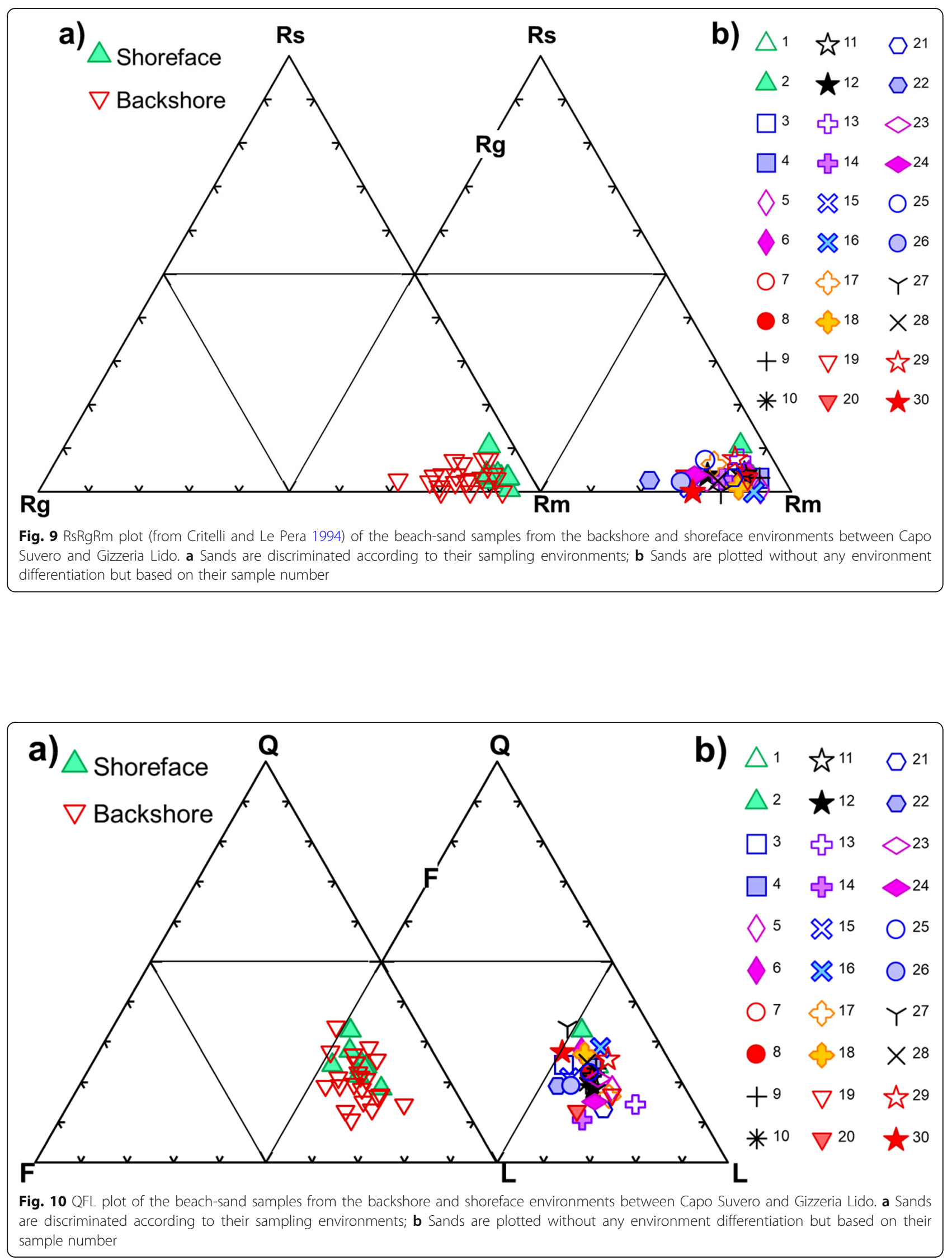
shoreface sands. Previous studies (Le Pera and Critelli 1997; Le Pera et al. 2000) asserted that the coastal area between Capo Suvero and Gizzeria Lido belongs to a wider coastal petrologic province, namely Santa Eufemia Littoral Province, characterized by a quartzofeldspathic petrofacies with dominant metamorphic lithic grains provided mainly from the Amato and Angitola rivers. The Amato and Angitola rivers flow across gneiss and plutonic rocks with minor ophiolitic and sedimentary rocks, ending in the alluvial deposits of the Santa Eufemia Plain. Furthermore, a high local concentration of garnet was recognized also by Brondi et al. (1972) especially at the $-10 \mathrm{~m}$ isobath adjacent to the Angitola river-mouth, derived from the crystalline units comprising garnet-sillimanite-bearing gneiss (e.g. AmodioMorelli et al. 1976).

The distribution of the studied detrital grains helped to clarify the transport processes, which caused a small reduction in the abundance of most mechanically unstable sand-grade grains from backshore to shoreface (i.e., $\% \operatorname{Rg}_{14} \mathrm{Rs}_{3} \mathrm{Rm}_{83}-\mathrm{OQ}_{21} \mathrm{~F}_{22} \mathrm{~L}_{57}$ for backshore sands and $\% \mathrm{Rg}_{7} \mathrm{Rs}_{4} \mathrm{Rm}_{89}-\mathrm{QQ}_{31} \mathrm{~F}_{18} \mathrm{~L}_{51} \%$ for shoreface sands, respectively). These losses due to mechanical breakage and abrasion can be regarded as only minor from the backshore to the shoreface zone. This kind of minor losses suggests a relatively short transport process from backshore to shoreface environments, which is also confirmed by the grain-size analysis (Table 2; Fig. 5). In fact, by comparing monomineralic and polymineralic grains (Fig. 7), there exists a relationship between grain size and sand composition in terms of single crystals and rock fragments, which suggests a lower textural maturity of the backshore sand samples with respect to the shoreface ones. The trend (Fig. 7) may indicate that the shoreface sand samples suffered more efficient reworking by sea-waves and a relatively longer transport than the backshore sediments. This process implies less time in terms of breakage process efficiency, such as the conversion from polymineralic rock fragments to single-crystal grains (e.g. Le Pera and Morrone 2020). The grade of textural maturity is also supported by the grain-size results: in the backshore environment the samples are characterized by very coarse and coarse sand fractions, whereas in the shoreface environment the samples exhibit different grain size fractions, from very coarse to fine sand (Table 2; Fig. 5).

The proportions of monocrystalline feldspars (F) and aphanitic lithic fragments (L) both tend to decline from backshore to shoreface sands (Fig. 10), which can be expected based on the evaluation on transport processes of the monomineralic grains and rock fragments (e.g. Arribas and Arribas 2007; James et al. 2007; Picard and McBride 2007; Morrone et al. 2018). There is a high decrease of plutonic/gneissic rock fragments $\left(R_{g}\right.$ pole in Fig. 9) in the backshore and shoreface sands, probably because discontinuities within the plutoniclastic/gneissiclastic detritus, especially happening along no-isomineralic interfaces, control rock disaggregation (e.g. Heins 1995; Caracciolo et al. 2012; Weltje et al. 2018; Le Pera and Morrone 2020) through the mechanical disintegration by vigorous waves and currents of the Capo Suvero-Gizzeria Lido hydrodynamic regime. Variations in the proportion of specific grain types, detected between backshore and shoreface environments, indicate that changes occurred in the relative influence of fluvial input to marine sedimentation and in the longshore component of sediment movements (e.g. Mack 1978; Ingersoll et al. 1993; Critelli et al. 1997; Garzanti et al. 2014). Overall, the discriminated sandy petrofacies does not change between backshore and shoreface environments (Figs. 9, 10) and even labile lithic types survive in the Savuto and Amato river transport system to reach the Tyrrhenian coastline.

In the central Tyrrhenian Calabria coast, previous studies (Le Pera and Critelli 1997; Le Pera and Sorriso-Valvo 2000a; Le Pera et al. 2000) identified, at the Capo Suvero promontory, the boundary between the two littoral petrological provinces (Santa Eufemia Littoral Province and Coastal Range Littoral Province), and found no significant southward mixing of sand between the two provinces. The present research shows that the Capo Suvero promontory does not represent an obstruction to the sedimentary littoral transport, but that alternatively, during winter storms, sand from the northern petrofacies can be remobilized under higher-energy wave regimes passing the Capo Suvero promontory. Indeed, a detrital signature from the Savuto River was found in the southernmost area of the Capo Suvero promontory. In particular, serpentinite lithic fragments testify their origin and transport from the small high-pressure and lowtemperature complex of blue schists outcropping in the Coastal Range and point to a southward drift. Among the analyzed samples, a specific mineral assemblage indicative of an exclusive sediment provenance was not found, because the dominating lithology in the Amato Basin also crops out in the Savuto Basin. Indeed, the sediments of the Amato Basin differ from those of the Savuto Basin by their amount of some detrital grains such as aphanitic lithic grains, quartz and feldspars (Le Pera and Critelli 1997). As a consequence, the mineral assemblage recognized in the analyzed samples shows a clear provenance from the Savuto River and a supply compatible with that of the Amato and Angitola rivers. Thus, the composition 
study cannot provide specific evidence for a petrological mixing of the sediments supplied by Savuto and Amato rivers, even if this mixing could be compatible and cannot be excluded. Using the mineropetrographic approach to study the sedimentary provenance of the beach sands showed some limitations because of the homogeneity of source rocks in the analyzed basins, thus, further information to understand the beach processes needs to be provided by geomorphological study. Such studies, including the reconstruction of the historical shorelines and the determination of the terminal directions of the rivers and streams, seem to indicate the existence of two littoral currents with opposite directions. In particular, the reconstruction of the historical shoreline evolution shows a fast modification of the beach, where construction and dismantling of spits occurred in the period of 1870-2019.

During the analyzed period, remarkable erosion phenomena were observed mainly during the second half of the last century. According to previous studies (e.g. Ietto 2001; D'Alessandro et al. 2002; Aiello et al. 2013), the deficit in coastal sediment supply was caused by numerous instances of human activities inside the hydrographic basins, such as the construction of infrastructures and buildings close to the coastline, the uncontrolled sand mining in river beds and river engineering works. However, the geomorphological beach evolution of the last 150 years shows that the spits in the La Vota area are always marked by a south-directed growth, whereas in the Maricello area the spits are characterized by changing growth directions over the time. The opposite growth direction of the spits (from north to south or from south to north), observed in some historical shoreline comparisons, would support the hypothesis of two littoral currents with opposite directions. The different growth directions of the spits may depend on the prevalence of one or of the other current during different seasons. This hypothesis is also supported by reconstructing the changes of the terminal course directions of rivers and streams in the southern and northern part of the study area. Thus, the two littoral currents may be oriented towards south in the northern part of the study area and oriented towards north in the southern part, converging in the area between Capo Suvero and Gizzeria Lido (Fig. 11). The occurrence of converging currents appears to be an important factor both for the mineralogical mixing and for the geomorphological evolution of the beach, because it could generate vortex motions and then cause a fast remodeling of the coast with a presumable offshore sediment flow. Similar current regimes have been observed and argued by several authors worldwide (e.g. Magnell et al. 1990; Mathew and Baba 1995; Reddy 2001; Cenedese et al. 2013).

\section{Conclusions}

The aims of this research concern the reconstruction of the historical evolution of the shoreline since the year 1870, and the modern sand composition between Capo Suvero promontory and Gizzeria Lido. The geomorphological study suggests that the studied littoral area was highly dynamic between 1870 and 2019, with frequent and fast modifications of the beaches, consisting in construction and dismantling of spits. The sand composition was analyzed through the study of the detrital grains, which allowed an assessment of the petrological-sedimentary source and the dispersal pathway.

The main conclusions are as follows:

1) The sandy petrofacies does not differ between backshore and shoreface environments, suggesting relatively short transport processes which had little effect on sand composition and texture.

2) The detrital modes indicate a predominant source located on the north side of the study area, the Savuto River. This river flows across the Coastal Range, and its detrital mineralogy consists of an assemblage dominated by Schist+Phyllite+Serpentinite lithic fragments. Serpentinite lithic fragments testify its provenance from a small high-pressure and lowtemperature complex of blue schists outcropping in the Coastal Range. Furthermore, the analyzed mineral assemblage, consisting of aphanitic lithic grains, quartz and feldspars, shows a compatible supply from both the Amato and Savuto rivers (basins).

3) The RgRsRm composition plot is better than QFL composition suited for discriminating sand provenance. It provides additional information, because the contribution from minor sources (or with a low Sand Generation Index) such as the blue schists and serpentinites could be identified, which would be diluted and/or unrecognizable using only the QFL approach.

4) Capo Suvero promontory does not have a sufficient seaward extent to obstruct longshore sand transport. Bypassing of sand from the northern petrofacies beyond the Capo Suvero promontory during winter storms, cannot be ruled out.

5) Geomorphological study supports the hypothesis of two littoral currents with opposite directions in the stretch of coast between Capo Suvero and Gizzeria Lido. The littoral currents are oriented southward on the northern side and northward on the remaining southern side. A possible vortex motion, 


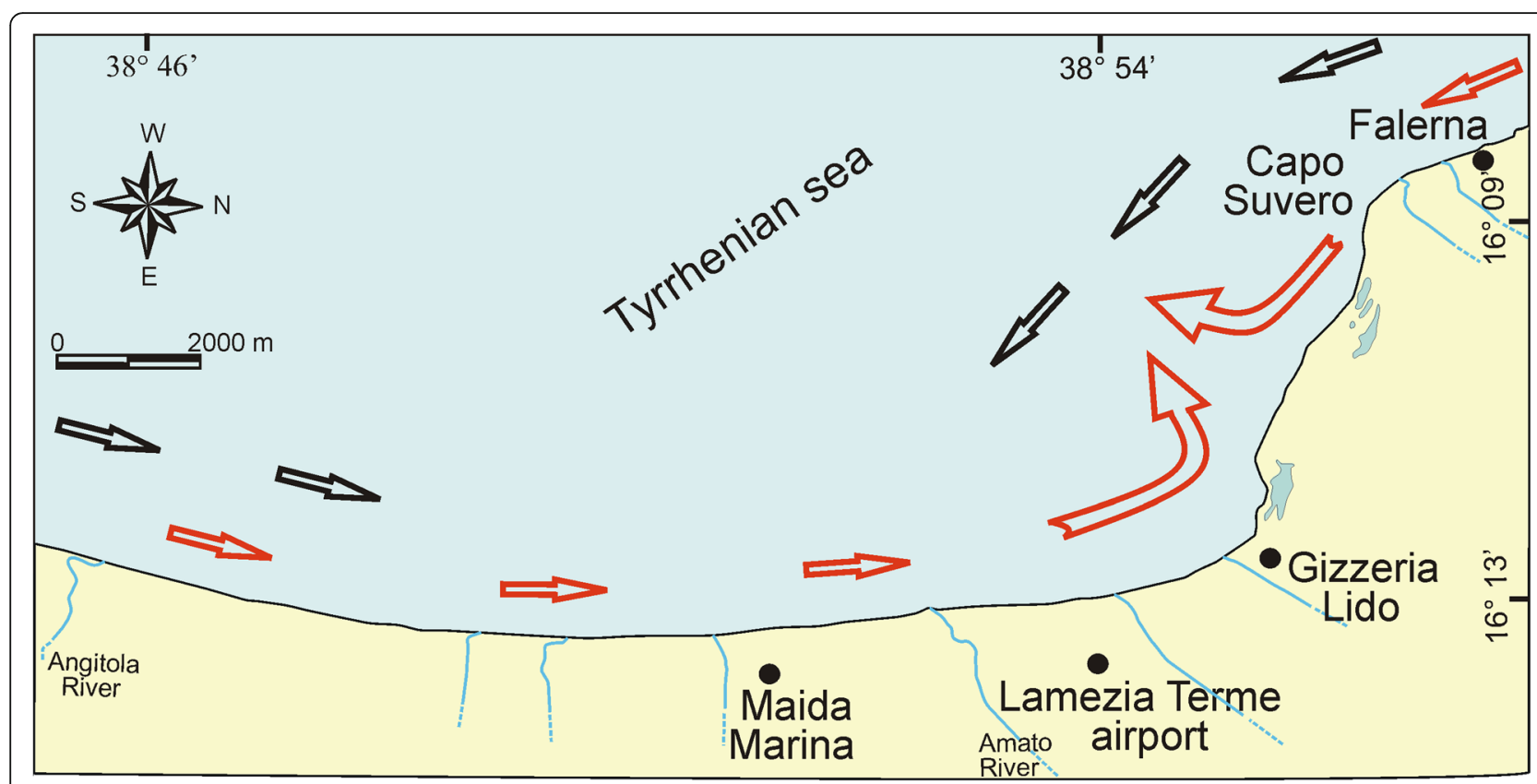

Fig. 11 Schematic diagram showing two littoral currents with opposite directions at the coast between Capo Suvero and Gizzeria Lido. The black arrows show littoral currents according to previous studies (e.g. Lupia Palmieri and Raffi 1983; D’Alessandro et al. 1992; Le Pera and Critelli 1997); the red illustrate our hypothesis concerning the drift direction and littoral currents

generated from these littoral currents, may be the cause of the fast coast remodeling.

This research highlights the importance and the great potential of multidisciplinary approaches involving different branches of geosciences for studying coastal areas, in the present case documenting the synergy between geomorphology and sedimentary petrography. The used approach may be considered as a key case applicable to similar studies on geomorphological evolution and provenance analyses of other littoral areas in comparable geodynamic settings.

\section{Abbreviations}

Q: Quartz (monocrystalline and polycrystalline quartz excluding chert);

F: Feldspar (monocrystalline feldspars+granitic/gneissic grains); L: Lithic grains (aphanitic lithic grains); Rg: Granitoid (granitic+gneissic) rock fragments (plutonic rock+gneiss rock fragments); Rs: Sedimentary rock fragments (both siliciclastic and carbonate lithic fragments); Rm: Metamorphic rock fragments (schist+phyllite lithic fragments); CPA: Calabria-Peloritani Arc; DGPS: Differential Global Position System; GIS: Geographic Information System

\section{Supplementary Information}

The online version contains supplementary material available at https://doi. org/10.1186/s42501-021-00088-y.

Additional file 1. Point-counting raw data.

Additional file 2. Recalculated petrographic parameters.

\section{Acknowledgements}

The authors are indebted to editors and anonymous reviewers for their comments and useful suggestions, which were constructive for improving the quality of the manuscript. We would like to thank Giulia Brescia and Alessandra De Marco for their help to collect the beach samples.

\section{Authors' contributions}

$\mathrm{CM}$ and $\mathrm{Fl}$ contributed to the conception of the study, acquired the samples in the field, performed the research, and wrote the manuscript. Both authors contributed to read and to approve the final manuscript.

\section{Funding}

This study was funded by MIUR (Ministero dell'Istruzione, dell'Università e della Ricerca), ex 60\% fund (2019 year) to Fabio letto.

\section{Availability of data and materials}

All data generated and analyzed during this study are included in this published article.

\section{Declarations}

\section{Competing interests}

The authors declare that they have no competing interests.

Received: 24 September 2020 Accepted: 4 March 2021

Published online: 19 March 2021

\section{References}

Aiello, A., F. Canora, and G. Spilotro. 2013. Coastal erosion and sediment deficit assessment at catchment basin scale: A case study from southern Italy. Rendiconti Online Società Geologica Italiana 24: 9-11.

Amodio-Morelli, L., G. Bonardi, V. Colonna, D. Dietrich, G. Giunta, F. Ippolito, V. Liguori, S. Lorenzoni, A. Paglionico, V. Perrone, G. Piccarreta, M. Russo, P. Scandone, E. Zanettin-Lorenzoni, and A. Zuppetta. 1976. L'Arco 
Calabro-Peloritano nell'orogene appenninico-maghrebide. Società Geologica Italiana Memorie 17: 1-60.

Anfuso, G., and F.J. Gracia. 2005. Morphodynamic characteristics and shortterm evolution of a coastal sector in SW Spain: Implications for coastal erosion management. Journal of Coastal Research

21 (6): 1139-1153.

Antonioli, F., L. Ferranti, K. Lambeck, S. Kershaw, V. Verrubbi, and G. Dai Pra. 2006. Late Pleistocene to Holocene record of changing uplift rates in southern Calabria and northeastern Sicily (southern Italy, central Mediterranean Sea). Tectonophysics 422 (1-4): 23-40. https://doi.org/10.1 016/j.tecto.2006.05.003.

Arribas, J., and M.E. Arribas. 2007. Interpreting carbonate particles in modern continental sands: An example from fluvial sands (Iberian Range, Spain). In: Arribas, J., S. Critelli, and M. Johnsson, (Eds.). Sedimentary provenance and petrogenesis: Perspectives from petrography and geochemistry. Geological Society of America Special Papers 420: 167-179. https://doi. org/10.1130/2006.2420(11)

Bagdanavičiūtè, I., L. Kelpšaitè, and T. Soomere. 2015. Multi-criteria evaluation approach to coastal vulnerability index development in micro-tidal low-lying areas. Ocean Coastal Management 104: 124-135. https://doi.org/10.1016/j.ocecoaman.2014.12.011.

Bakker, W.T. 2013. Coastal Dynamics. In: Advanced Series on Ocean Engineering. World Scientific Publishing Co., Singapore: p. 114.

Boak, E.H., and I.L. Turner. 2005. Shoreline definition and detection: A review. Journal of Coastal Research 21 (4): 688-703.

Bonardi, G., W. Cavazza, V. Perrone, and S. Rossi. 2001. Calabria-Peloritani Terrane and northern Ionian Sea. In: Vai, G.B., and I.P. Martini. (Eds.). Anatomy of an Orogen: The Apennines and Adjacent Mediterranean Basins. Kluwer Academic Publishers, Dordrecht, Netherlands: pp. 287306.

Brondi, A., O. Ferretti, B. Anselmi, and F. Benvegnu. 1972. Studi mineralogici e sedimentologici della piattaforma costiera calabrese nel tratto compreso tra Briatico e la foce del Fiume Angitola. Società Italiana Mineralogia e Petrologia 28 (1): 3-29 (in Italian).

Calcaterra, D., and M. Parise. 2010. Weathering as a predisposing factor to slope movements. Geological Society, London, Special Publications 23 (1): 105-130. https://doi.org/10.1144/EGSP23.7.

Caloiero, D. 1975. Le precipitazioni in Calabria nel cinquantennio 1921-70 e carta delle isoiete alla scala 1:500,000. Cosenza: CNR-IRPI Istituto di ricerca per la protezione idrogeologica.

Calvã, T., M.F. Pessoa, and F.C. Lidon. 2013. Impact of human activities on coastal vegetation: A review. Emirates Journal of Food and Agriculture 25 (12): 926-944.

Cantasano, N., G. Pellicone, and F. letto. 2017. Integrated coastal zone management in Italy: A gap between science and policy. Journal of Coastal Conservation 21 (3): 317-325. https://doi.org/10.1007/s11852-01 6-0479-z.

Cantasano, N., G. Pellicone, and F. letto. 2020. The coastal sustainability standard method: A case study in Calabria (southern Italy). Ocean Coastal Management 183: 104962. https://doi.org/10.1016/j.ocecoaman.2 019.104962

Caprio, A., G. Maiorca, and G. Spampinato. 1999. Prospettive per il recupero e la protezione dei laghi "La Vota". Calabria Verde 3 (5): 42-47 (in Italian).

Caracciolo, L., E. Le Pera, F. Muto, and F. Perri. 2011. Sandstone petrology and mudstone geochemistry of the Peruc-Korycany formation (bohemian cretaceous basin, Czech Republic). International Geology Review 53 (9): 1003-1031. https://doi.org/10.1080/00206810903429011.

Caracciolo, L., R. Tolosana-Delgado, E. Le Pera, H. von Eynatten, J. Arribas, and S. Tarquini. 2012. Influence of granitoid textural parameters on sediment composition: Implications for sediment generation. Sedimentary Geology 280: 93-107. https://doi.org/10.1016/j.sedgeo.2012. 07.005.

Carrara, A., and G.G. Zuffa. 1976. Alpine structures in northwestern Calabria, Italy. Geological Society of America Bulletin 87 (9): 1229-1246. https://doi. org/10.1130/0016-7606(1976)87<1229:ASINCl>2.0.CO;2.

Castelle, B., M. Vincent, S. Bujan, K.D. Splinter, A. Robinet, N. Sénéchal, and S. Ferreiraa. 2015. Impact of the winter 2013-2014 series of severe
Western Europe storms on a double-barred sandy coast: Beach and dune erosion and megacusp embayments. Geomorphology 238: 135148. https://doi.org/10.1016/j.geomorph.2015.03.006.

Catalano, S., and G. De Guidi. 2003. Late Quaternary uplift of northeastern Sicily: Relation with the active normal faulting deformation. Journal of Geodynamics 36 (4): 445-467. https://doi.org/10.1016/S0264-3707(02 )00035-2.

Cenedese, C., R.S. Todd, G.G. Gawarkiewicz, and W.B. Owens. 2013. Offshore transport of shelf waters through interaction of vortices with a shelfbreak current. Journal of Physical Oceanography 43 (5): 905-919. https://doi.org/10.1175/JPO-D-12-0150.1.

Chaudhuri, A., S. Banerjee, and E. Le Pera. 2018. Petrography of middle Jurassic to early cretaceous sandstones in the Kutch Basin, western India: Implications on provenance and basin evolution. Journal of Palaeogeography 7 (2): 2-14. https://doi.org/10.1186/s42501-018-0002-6.

Chiocci, F.L. 1994. Very high-resolution seismics as a tool for sequence stratigraphy applied to outcrop scale-examples from eastern Tyrrhenian margin Holocene/Pleistocene deposits. American Association of Petroleum Geologists Bulletin 78: 378-395.

Chiocci, F.L., S. D'angelo, L. Orlando, and A. Pantaleone. 1989. Evolution of the Holocene shelf sedimentation defined by high resolution seismic stratigraphy and sequence analysis (Calabro-Tyrrhenian continental shelf). Memorie Società Geologica Italiana 48: 359-380.

Conforti, M., and F. letto. 2019. An integrated approach to investigate slope instability affecting infrastructures. Bulletin of Engineering Geology and the Environment 78 (4): 2355-2375. https://doi.org/10.1007/s10064-01 8-1311-9.

Conforti, M., and F. letto. 2020. Influence of tectonics and morphometric features on the landslide distribution: A case study from the Mesima Basin (Calabria, South Italy). Journal of Earth Science 31 (2): 393-409. https://doi.org/10.1007/s12583-019-1231-z.

Critelli, S., J. Arribas, E. Le Pera, A. Tortosa, K.M. Marsaglia, and K.L. Latter 2003. The recycled orogenic sand provenance from an uplifted thrustbelt, Betic cordillera, southern Spain. Journal of Sedimentary Research 73 (1): 72-81. https://doi.org/10.1306/071002730072.

Critelli, S., and R.V. Ingersoll. 1995. Interpretation of neovolcanic versus palaeovolcanic sand grains: An example from Miocene deep-marine sandstone of the Topanga group (Southern California). Sedimentology 42 (5): 783-804. https://doi.org/10.1111/j.1365-3091.1995.tb00409.x.

Critelli, S., and E. Le Pera. 1994. Detrital modes and provenance of Miocene sandstones and modern sands of the southern Apennines thrust-top basins (Italy). Journal of Sedimentary Research A64: 824-835.

Critelli, S., and E. Le Pera. 1995. Tectonic evolution of the southern Apennines thrust-belt (Italy) as reflected in modal compositions of Cenozoic sandstone. Journal of Geology 103 (1): 95-105. https://doi. org/10.1086/629725.

Critelli, S., and E. Le Pera. 2003. Provenance relations and modern sand petrofacies in an uplifted thrust-belt, northern Calabria, Italy. Memorie Descrittive Carta Geologica d'tialia LXI: 25-38.

Critelli, S., E. Le Pera, and R.V. Ingersoll. 1997. The effects of source lithology, transport, deposition and sampling scale on the composition of southern California sand. Sedimentology 44 (4): 653-671. https://doi. org/10.1046/j.1365-3091.1997.d01-42.x.

Cutroneo, L., G. Ferretti, D. Scafidi, G.D. Ardizzone, G. Vagge, and M. Capello. 2017. Current observations from a looking down vertical V-ADCP: Interaction with winds and tide? The case of Giglio Island (Tyrrhenian Sea, Italy). Oceanologia 59 (2): 139-152. https://doi.org/10.1016/j.ocea no.2016.11.001.

D'Alessandro, L., L. Davoli, E. Lupia Palmieri, and R. Raffi. 1992. Recent dynamics of the Tyrrhenian beaches of Calabria (southern Italy). Bollettino di Geofisica Teorica e Applicata 10: 187-195.

D'Alessandro, L., L. Davoli, E. Lupia Palmieri, and R. Raffi. 2002. Natural and anthropogenic factors of the recent evolution of the Calabria beaches. In: Allison, R.J. (Ed.). Applied geomorphology: Theory and practice. Wiley, New York, 22: 397-427.

D'Alessandro, L., and E. Lupia Palmieri. 1981. Lineamenti morfologici ed evoluzione della spiaggia emersa. In: Lupia Palmieri, E. (Ed.). Primi 
risultati delle indagini di geografia fisica, sedimentologia e idraulica marittima sul litorale del Golfo di Santa Eufemia. Progetto Finalizzato "Conservazione del suolo" - sottoprogetto "Dinamica dei litorali". C.N.R. Pubbl. 127: 25-36.

Dawson, R.J., M. Dickson, R.J. Nicholls, and J. Hall. 2009. Integrated analysis of risks of coastal flooding and cliff erosion under scenarios of long term change. Climatic Change 95 (1-2): 249-288. https://doi.org/10.1 007/s10584-008-9532-8.

Del Río, L., F.J. Gracia, and J. Benavente. 2013. Shoreline change patterns in sandy coasts. A case study in SW Spain. Geomorphology 196: 252-266.

Demirpolat, S., and W.F., Tanner. 1991. Keys to high-accuracy mapping of shoreline changes. In: Kraus, N.C., K.J. Gingerich, and D.L. Kriebel. (Eds.). Coastal Sediments '91. American Society of Civil Engineers, Seattle, pp. 1054-1068.

Dewey, J.F., M.L. Helman, E. Turco, D.H.W. Hutton, and S.D. Knott. 1989. Kinematics of the Western Mediterranean. In: Coward, M.P., D. Dietrich, and R.G. Park. (Eds.). Alpine Tectonics. Geological Society, London, Special Publications 45: 265-284.

Di Paola, G., P.P.C. Aucelli, G. Benassai, and G. Rodríguez. 2013. Coastal vulnerability to wave storms of Sele littoral plain (southern Italy). Natural Hazards 71: 1795-1819.

Dickinson, W.R. 1988. Provenance and sediment dispersal in relation to paleotectonics and paleogeography of sedimentary basins. In: Kleinspehn, K.L., and C. Paola. (Eds.). New Perspectives in Basin Analysis: Frontiers in Sedimentary Geology. Springer, New York, pp. 3-25.

Dickinson, W.R., and C.A. Suczek. 1979. Plate tectonics and sandstone compositions. American Association of Petroleum Geologist Bulletin 63: 2164-2182.

Dolan, R., B.P. Hayden, P. May, and S.K. May. 1980. The reliability of shoreline change measurements from aerial photographs. Shore and Beach 48 (4): 22-29.

Ferranti, L., F. Antonioli, M. Anzidei, C. Monaco, and P. Stocchi. 2010. The timescale and spatial extent of recent vertical tectonic motions in Italy: Insights from relative sea-level changes studies. Journal of the Virtual Explorer 36: 30.

Ferrarin, C., A. Roland, M. Bajo, G. Umgiesser, A. Cucco, S. Davolio, A. Buzzi, P. Malguzzi, and O. Drofa. 2013. Tide-surge-wave modelling and forecasting in the Mediterranean Sea with focus on the Italian coast Ocean Modelling 61: 38-48. https://doi.org/10.1016/j.ocemod.2012.10. 003.

Ferreira, O. 2006. The role of storm groups in the erosion of sandy coasts. Earth Surface Processes and Landforms 31 (8): 1058-1060. https://doi. org/10.1002/esp.1378.

Forbes, C. 2009. The effects of climate change induced coastal inundation. National Environmental Law Review 4: 44-57.

Gaillard, P., P. Ravazzola, C. Kontolios, L. Arrivet, G.A. Athanassoulis, C.N. Stefanakos, T.P. Gerostathis, L. Cavaleri, L. Bertotti, M. Sclavo, E. Ramieri, L. Dentone, C. Noel, C. Viala, and J.M. Lefevre. 2004. Wind and wave atlas of the Mediterranean Sea, Western European Armaments Organisation, Research Cell, Technical Report, 386.

Galli, P., and V. Bosi. 2002. Paleoseismology along the Cittanova fault: Implications for seismotectonics and earthquake recurrence in Calabria (southern Italy). Journal of Geophysical Research 107 (B3): 1-19.

Garzanti, E., M. Padoan, M. Setti, A. López-Galindo, and I.M. Villa. 2014. Provenance versus weathering control on the composition of tropical river mud (southern Africa). Chemical Geology 366: 61-74. https://doi. org/10.1016/j.chemgeo.2013.12.016.

Gervais, M., Y. Balouin, and R. Belona. 2012. Morphological response and coastal dynamics associated with major storm events along the Gulf of lions coastline, France. Geomorphology 143-144: 69-80.

Ghisetti, F., and L. Vezzani. 1982. The recent deformation mechanism of the Calabrian arc. Earth Evolution Sciences 3 (2): 197-206.

Guiducci, F., and G. Paolella. 2004. Learning from 20 years of design and realization on coastal protection over the Tyrrhenian Calabrian coast. In: $29^{\text {th }}$ ICCE International Conference on Coastal Engineering. World Scientific Press, Lisbon: pp. 3826-3838.
Hapke, C.J., D. Reid, and B. Richmond. 2009. Rates and trends of coastal change in California and the regional behavior of the beach and cliff system. Journal Coastal Research 25 (3): 603-615.

Heins, W.H. 1995. The use of mineral interfaces in sand-sized rock fragments to infer ancient climate. Geological Society of America Bulletin 107 (1): 113-125. https://doi.org/10.1130/0016-7606(1995)107<0113:TUOMII>2.3. $\mathrm{CO} ; 2$.

Hinkel, J., R.J. Nicholls, R.S.J. Tol, Z.B. Wang, J.M. Hamilton, G. Boot, A.T. Vafeidis, L. McFadden, A. Ganopolski, and R.J.T. Klein. 2013. A global analysis of erosion of sandy beaches and sea-level rise: An application of DIVA. Global and Planetary Change 111: 150-158. https://doi.org/10.1 016/j.gloplacha.2013.09.002.

Hoitink, A.J.F., and D.A. Jay. 2016. Tidal river dynamics: Implications for deltas. Reviews of Geophysics 54 (1): 240-272. https://doi.org/10.1002/201 5RG000507.

Iannace, A., G. Bonardi, M. D'errico, S. Mazzoli, V. Perrone, and S. Vitale. 2005. Structural setting and tectonic evolution of the Apennine units of northern Calabria. Comptes Rendus Geosciences 337 (16): 1541-1550. https://doi.org/10.1016/j.crte.2005.09.003.

Ibbeken, H., and R. Schleyer. 1991. Source and sediment. In A case study of provenance and mass balance at an active plate margin (Calabria, southern Italy), 286. Berlin: Springer-Verlag. https://doi.org/10.1007/978-3642-76165-2.

letto, A., and F. letto. 2004. Age and history of the weathering of granitoids in southern Calabria (Italy). Geografia Fisica e Dinamica Quaternaria 27: $37-45$.

letto, F. 2001. Evolution of the north Tyrrhenian Calabrian beaches in the last 50 years. Alpine Mediterranean Quaternary 14 (2): 105-116.

letto, F., N. Cantasano, and G. Pellicone. 2018a. A new coastal erosion risk assessment indicator: Application to the Calabria Tyrrhenian Littoral (southern Italy). Environmental Processes 5 (2): 201-223. https://doi.org/1 0.1007/s40710-018-0295-6.

letto, F., N. Cantasano, and F. Salvo. 2014. The quality of life conditioning with reference to the local environmental management: A pattern in Bivona country (Calabria, southern Italy). Ocean Coastal Management 102: 340-349. https://doi.org/10.1016/j.ocecoaman.2014.10.014.

letto, F., E. Le Pera, and L. Caracciolo. 2012a. Geomorphology and sand provenance of the Tyrrhenian coast between capo Suvero and Gizzeria (Calabria, southern Italy). Rendiconti Online Società Geologica Italiana 21: 487-488.

letto, F., E. Le Pera, and F. Perri. 2013. Weathering of the 'Rupe di Tropea' (southern Calabria): Consolidation criteria and erosion-rate estimate. Rendiconti Online Società Geologica Italiana 24: 178-180.

letto, F., M. Parise, M. Ponte, and D. Calcaterra. 2012b. Geotechnical characterization and landslides in the weathered granitoids of Calabria (southern Italy). Rendiconti Online Società Geologica Italiana 21: 551-552.

letto, F., and F. Perri. 2015. Flash flood event (October 2010) in the Zinzolo catchment (Calabria, southern Italy). Rendiconti Online Società Geologica Italiana 35: 170-173. https://doi.org/10.3301/ROL.2015.92.

letto, F., F. Perri, and F. Cella. 2016. Geotechnical and landslide aspects in weathered granitoid rock masses (serre massif, southern Calabria, Italy). Catena 145: 301-315. https://doi.org/10.1016/j.catena.2016.06.027.

letto, F., F. Perri, and F. Cella. 2018b. Weathering characterization for landslides modelling in granitoid rock masses of the Capo Vaticano promontory (Calabria, Italy). Landslides 15 (1): 43-62. https://doi.org/10.1 007/s10346-017-0860-5.

letto, F., F. Perri, and G. Fortunato. 2015. Lateral spreading phenomena and weathering processes from the Tropea area (Calabria, southern Italy). Environmental Earth Science 73 (8): 4595-4608. https://doi.org/10.1007/ s12665-014-3745-0.

Ingersoll, R.V. 1990. Actualistic sandstone petrofacies: Discriminating modern and ancient source rocks. Geology 18 (8): 733-736. https://doi.org/10.113 0/0091-7613(1990)018<0733:ASPDMA>2.3.CO;2.

Ingersoll, R.V., T.F. Bullard, R.L. Ford, J.P. Grimm, J.D. Pickle, and S.W. Sares. 1984. The effect of grain size on detrital modes: A test of the GazziDickinson point-counting method. Journal of Sedimentary Research 54: 103-116. 
Ingersoll, R.V., A.G. Kretchmer, and P.K. Valles. 1993. The effect of sampling scale on actualistic sandstone petrofacies. Sedimentology 40 (5): $937-$ 953. https://doi.org/10.1111/j.1365-3091.1993.tb01370.x.

James, D.E., A.M. DeVaughn, and K.M. Marsaglia. 2007. Sand and gravel provenance in the Waipoa River system: Sedimentary recycling in an actively deforming forearc basin, North Island, New Zealand. In: Arribas J., S. Critelli, and M.J. Johnsson. (Eds.). Sedimentary provenance and petrogenesis: Perspectives from petrography and geochemistry. Geological Society of America Special Papers 420: 253-276.

James, I.D. 1974. Non-linear waves in the nearshore region: Shoaling and set-up. Estuarine, Coastal and Shelf Science 2 (3): 207-234. https://doi. org/10.1016/0302-3524(74)90013-9.

Johnsson, M.J. 1993.The system controlling the composition of clastic sediments. In: Johnsson, M.J., and A. Basu. (Eds.). Processes Controlling the Composition of Clastic Sediments. Geological Society of America Special Papers 284: 1-19. https://doi.org/10.1130/SPE284-p1.

Komar, P.D. 1998. Beach processes and sedimentation. 2nd ed, 543. Englewood Cliffs: Prentice Hall.

Krause, G., and C. Soares. 2004. Analysis of beach morphodynamics on the Bragantinian mangrove peninsula (Pará, North Brazil) as prerequisite for coastal zone management recommendations. Geomorphology 60 (1-2): 225-239. https://doi.org/10.1016/j.geomorph.2003.08.006.

Le Pera, E., J. Arribas, S. Critelli, and A. Tortosa. 2001. The effects of source rocks and chemical weathering on the petrogenesis of siliciclastic sand from the Neto River (Calabria, Italy): Implications for provenance studies. Sedimentology 48 (2): 357-378. https://doi.org/10.1046/j.1365-3091.2001. 00368.x.

Le Pera, E., and S. Critelli. 1997. Sourceland controls on the composition of beach and fluvial sand of the Tyrrhenian coast of Calabria, Italy: Implications for actualistic petrofacies. Sedimentary Geology 110 (1-2): 81-97. https://doi.org/10.1016/S0037-0738(96)00078-4

Le Pera, E., G. Mongelli, F. Morelli, and S. Critelli. 2000. Compositional and geochemical signature of provenance in modern sediments from the Tyrrhenian continental shelf, Calabria, Italy. Giornale di Geologia 62: $37-$ 55.

Le Pera, E., and C. Morrone. 2018. Heavy minerals distribution and provenance in modern beach sands of Campania, Italy. Rendiconti Online Società Geologica Italiana 45: 136-140. https://doi.org/10.3301/ ROL.2018.41.

Le Pera, E., and C. Morrone. 2020. The use of mineral interfaces in sandsized volcanic rock fragments to infer mechanical durability. Journal of Palaeogeography 9 (3): 288-313.

Le Pera, E., and M. Sorriso-Valvo. 2000a. Weathering and morphogenesis in a Mediterranean climate, Calabria, Italy. Geomorphology 34 (3-4): 251-270. https://doi.org/10.1016/S0169-555X(00)00012-X.

Le Pera, E., and M. Sorriso-Valvo. 2000b. Weathering, erosion and sediment composition in a high-gradient river, Calabria, Italy. Earth Surface Processes and Landforms 25 (3): 277-292. https://doi.org/10.1002/(SICl)1 096-9837(200003)25:3<277::AID-ESP79>3.0.CO:2-Z.

Lupia Palmieri, E., and R. Raffi. 1983. Atlante delle spiagge italiane: Dinamismo - Tendenza evo - lutiva - Opere umane. In: Fierro, G. (Ed.). S. EL.CA. Firenze, Sheets Scales 1:100,000. 108 pp.

Mack, G.H. 1978. The survivability of labile light-mineral grains in fluvial, aeolian and littoral marine environments: The Permian cutler and cedar Mesa formations, Moab, Utah. Sedimentology 25 (5): 587-604. https://doi. org/10.1111/j.1365-3091.1978.tb00321.x.

Magnell, B.A., N.A. Bray, C.D. Winant, C.L. Greengrove, J. Largier, J.F. Borchardt, R.L. Bernstein, and C.E. Dorman. 1990. Convergent shelf flow at Cape Mendocino. Oceanography 3 (1): 4-11. https://doi.org/10.5670/ oceanog.1990.14.

Masselink, G., and M.G. Hughes. 2003. Introduction to coastal processes and geomorphology, 354 pp. London: Edward Arnold.

Masselink, G., and A.D. Short. 1993. The effect of tidal range on beach morphodynamics and morphology: A conceptual beach model. Journal of Coastal Research 9: 785-800.

Mathew, J., and M. Baba. 1995. Mudbanks of the southwest coast of India. II: Wave-mud interactions. Journal of Coastal Research 11 (1): 179-187.
Mongardi, S., A. Correggiari, and F. Trincardi. 2004. Terrazzi deposizionali sommersi al largo di Capo Suvero (Calabria). Memorie Descrittive Carta Geologica Italiana LVIII: 63-74 (in Italian).

Moore, L.J., B.T. Benumof, and G.B. Griggs. 1999. Coastal erosion hazards in Santa Cruz and San Diego counties, California. Journal of Coastal Research Special Issue 28: 121-139.

Morrone, C., R. De Rosa, E. Le Pera, and K.M. Marsaglia. 2017. Provenance of volcaniclastic beach sand in a magmatic-arc setting: An example from Lipari island (Aeolian archipelago, Tyrrhenian Sea). Geological Magazine 154 (4): 804-828. https://doi.org/10.1017/5001675681600042X.

Morrone, C., E. Le Pera, R. De Rosa, and K.M. Marsaglia. 2018. Beach sands of Lipari Island, Aeolian archipelago: Roundness study. Rendiconti Online Società Geologica Italiana 45: 141-146. https://doi.org/10.3301/ROL.201 8.42.

Morrone, C., E. Le Pera, K.M. Marsaglia, and R. De Rosa. 2020. Compositional and textural study of modern beach sands in the active volcanic area of the Campania region (southern Italy). Sedimentary Geology 396: 105567. https://doi.org/10.1016/j.sedgeo.2019.105567.

Morten, L., and L. Tortorici. 1993. Geological framework of the ophiolitebearing allochtonous terranes of the calabrian arc and lucanian apennines. In: Morten, L. (Ed.) Italian Eclogites and Related Rocks. Accademia Nazionale delle Scienze XI: pp. 145-150.

Morucci, S., M. Picone, G. Nardone, and G. Arena. 2016. Tides and waves in the Central Mediterranean Sea. Journal of Operational Oceanography 9 (1): 10-17.

Nicholls, R.J., and F.M.J. Hoozemans. 1996. The Mediterranean: Vulnerability to coastal implications of climate change. Ocean Coastal Management 31 (2-3): 105-132. https://doi.org/10.1016/S0964-5691(96)00037-3.

Ortolani, F., M. Torre, B. Russo, and S. Di Nocera. 1979. Depositi alto miocenici del bordo settentrionale della Piana del Sele (Campania). Bollettino Società Geologica Italiana 98 (1): 3-14.

Ortolano, G., R. Cirrincione, and A. Pezzino. 2005. P-T evolution of Alpine metamorphism in the southern Aspromonte massif (Calabria - Italy). Schweizerische Mineralogische und Petrographische Mitteilungen 85: $31-$ 56.

Parry, M., O. Canziani, J. Palutikof, P. Van der Linden, and C. Hansen. 2007. Climate change: Impacts, adaptation and vulnerability, contribution of the working group II to the fourth assessment report of the intergovernmental panel on climate change, 315-357. Cambridge: Cambridge University Press.

Perri, F., F. letto, E. Le Pera, and C. Apollaro. 2016. Weathering processes affecting granitoid profiles of Capo Vaticano (Calabria, southern Italy) based on petrographic, mineralogic and reaction path modeling approaches. Geological Journal 51 (3): 368-386. https://doi.org/10.1002/ gj.2635.

Petrucci, O., G. Chiodo, and D. Caloiero. 1996. Eventi alluvionali in Calabria nel decennio 1971-1980, GNDCl, Pubb. 374. Rubbettino Arti Grafiche, Soveria Mannelli (CZ), 142.

Pezzino, A., G. Angì, E. Fazio, P. Fiannacca, A. Lo Giudice, G. Ortolano, R. Punturo, R. Cirrincione, and E. De Vuono. 2008. Alpine metamorphism in the Aspromonte massif: Implications for a new framework for the southern sector of the Calabria-Peloritani Orogen, Italy. International Geology Review 50 (5): 423-441. https://doi.org/10.2747/0020-6814.50. 5.423.

Phillips, M.R., and A.L. Jones. 2006. Erosion and tourism infrastructure in the coastal zone: Problems, consequences and management. Tourism Management 27 (3): 517-524. https://doi.org/10.1016/j.tourman.2005.10. 019.

Picard, M.D., and E.F. McBride. 2007. Comparison of river and beach sand composition with source rocks, Dolomite Alps drainage basins, northeastern Italy. In: Arribas J., S. Critelli, and M.J. Johnsson. (Eds.). Sedimentary provenance and petrogenesis: Perspectives from petrography and geochemistry. Geological Society of America Special Papers 420: pp. $1-12$.

Pirazzoli, P.A., G. Mastronuzzi, J.F. Saliège, and P. Sansò. 1997. Late Holocene emergence in Calabria, Italy. Marine Geology 141 (1-4): 61-70. https:// doi.org/10.1016/50025-3227(97)00057-1. 
Pranzini, E., and L. Rossi. 2014. Protocollo per il monitoraggio dell'evoluzione costiera. In: Cipriani, F. (Ed.). Monitoraggio dell'erosione costiera - una rete di osservatori regionali. Progetto ResMar, Firenze: pp. 8-56.

Punzo, M., C. Lanciano, D. Tarallo, F. Bianco, G. Cavuoto, R. De Rosa, V. Di Fiore, G. Cianflone, R. Dominici, M. lavarone, F. Lirer, N. Pelosi, L. Giordano, G. Ludeno, A. Natale, and E. Marsella. 2016. Application of Xband wave radar for coastal dynamic analysis: Case test of Bagnara Calabra (South Tyrrhenian Sea, Italy). Journal of Sensors Article ID 6236925: 1-9.

Reddy, M.P.M. 2001. Descriptive physical oceanography, 445. Mangalore.

Rete Ondametrica Nazionale. 2019. Istituto Superiore per la Protezione e la Ricerca dell'Ambiente (ISPRA). Available at http://dati.isprambiente.it/id/ website/ronRmn/html. Accessed on 30 July 2019.

Semedi, B., B.H. Husain, and N. Hidayati. 2016. Analyzing coastal vulnerability index using integrated satellite remote sensing and geographic information system: A case study of Denpasar coastal zone. Journal of Applied Environmental and Biological Sciences 6 (4): 35-40.

Sorriso-Valvo, M. 1993. The geomorphology of Calabria, a sketch. Geografia Fisica e Dinamica Quaternaria 16: 75-80

Sorriso-Valvo, M. 1997. Landsliding during the Holocene in Calabria, Italy. In: Matthews, J.A., D. Brunsden, B. Frenzel, B. Glaser, and M. Weiss. (Eds.) Rapid Mass Movement as a Source of Climatic Evidence for the Holocene. Brussels, Belgium: European Science Foundation, ESF Project, European Paleoclimate and Man Special Issue 12. Wiley, Chichester, pp. 97-108.

Sorriso-Valvo, M., L. Antronico, and E. Le Pera. 1998. Controls on modern fan morphology in Calabria, southern Italy. Geomorphology 24 (2-3): 169187. https://doi.org/10.1016/S0169-555X(97)00079-2.

Sorriso-Valvo, M., and A.G. Sylvester. 1993. The relationship between geology and landforms along a coastal mountain front, northern Calabria, Italy. Earth Surface Processes and Landforms 18 (3): 257-273. https://doi.org/10.1002/esp.3290180307.

Thomson, S.N. 1994. Fission track analysis of the crystalline basement rocks of the Calabrian arc, southern Italy: Evidence of Oligo-Miocene lateorogenic extension and erosion. Tectonophysics 238 (1-4): 331-352. https://doi.org/10.1016/0040-1951(94)90063-9.

Tortorici, L., C. Monaco, C. Tansi, and O. Cocina. 1995. Recent and active tectonics in the Calabrian arc (southern Italy). Tectonophysics 243 (1-2): 37-49. https://doi.org/10.1016/0040-1951(94)00190-K.

Trincardi, F., A. Correggiari, M.E. Field, and W.R. Normark. 1995. Turbidite deposition from multiple source: Quaternary Paola Basin (eastern Tyrrhenian Sea). Journal of Sedimentary Research B65: 469-483.

Vai, G.B. 1992. II segmento calabro-peloritano dell'orogene ercinico. Disaggregazione palinspastica. Bollettino Società Geologica Italiana 111: 109-129 (in Italian).

Van Rijn, L.C., D.J.R. Walstra, B. Grasmeijer, J. Sutherland, S. Pan, and J.P. Sierra. 2003. The predictability of crossshore bed evolution of sandy beaches at the time scale of storms and seasons using process-based profile models. Coastal Engineering 47 (3): 295-327. https://doi.org/10.1 016/S0378-3839(02)00120-5

Versace, P., E. Ferrari, S. Gabriele, and F. Rossi. 1989. Valutazione delle piene in Calabria. Centro Nazionale delle Ricerche- Istituto di ricerca per la protezione idrogeologica, Geodata 30: 1-232.

Weltje, G.J., B. Paredis, L. Caracciolo, and W.A. Heins. 2018. Quantitative analysis of crystal-interface frequencies in granitoids: Implications for modelling of parent-rock texture and its influence on the properties of plutoniclastic sands. Sedimentary Geology 375: 72-85. https://doi.org/1 0.1016/j.sedgeo.2018.01.004.

Westaway, R. 1993. Quaternary uplift of southern Italy. Journal of Geophysical Research 98 (B12): 21741-21772. https://doi.org/10.1029/93JB01566.

Zuffa, G.G. 1985. Optical analysis of arenites: Influence of methodology on compositional results. In: Zuffa, G.G. (Ed.). Provenance of Arenites. Reidel Dordrecht, pp. 165-190.

\section{Publisher's Note}

Springer Nature remains neutral with regard to jurisdictional claims in published maps and institutional affiliations.

\section{Submit your manuscript to a SpringerOpen ${ }^{\circ}$ journal and benefit from:}

- Convenient online submission

- Rigorous peer review

- Open access: articles freely available online

High visibility within the field

- Retaining the copyright to your article

Submit your next manuscript at $\boldsymbol{\nabla}$ springeropen.com 